\title{
Hegemons, Leaders and Followers: A Game-Theoretic Approach to the Postwar Dynamics of International Political Economy
}

\author{
by \\ Kjell Hausken and Thomas Plümper \\ Max-Planck-Institut für Gesellschaftsforschung \\ Lothringer Str. 78 \\ D-50677 Köln \\ Germany \\ mpi (a)mpi-fg-koeln.mpg.de \\ http://www.mpi-fg-koeln.mpg.de
}

v. 5/19/97

C 1997 Kjell Hausken and Thomas Plümper

Cite: Hausken, Kjell, and Thomas Plümper. (1997). "Hegemons, Leaders and Followers:

A Game-Theoretic Approach to the Postwar Dynamics of International Political

Economy." Joumal of World-Systems Research 3: 35 - 93.

\begin{abstract}
The article introduces the concept of hegemony to leadership theory, which has developed mainly as a critique of hegemonic stability theory. We argue that it makes sense to combine the two theories by introducing the concept of 'size' into neoliberal thinking about International Political Economy. We accept the neo-institutional hypothesis that a hegemon is not needed to provide public goods, and de monstrate with non-cooperative games how multiple leaders may jointly provide public goods. A gametheoretic model is developed illustrating with Nash equilibria the conditions under which a hegemon rationally switches from hegemony to leadership. It also shows why followers rationally switch from free-riding in their consumption of the public goods to taking part in leading, in the sense of contributing to covering the cost of the production of the public goods. The emergence of joint leadership leads to multiple equilibria in the sense of allowing for multiple stable leadership constellations. The actors are in a mixed-motive or coordination game where they have different preferences for the equilibria, and thus different preferences for which strategies to choose, and for who is to take part in covering the cost of the production of the public goods. Two aspects of joint leadership 'after hegemony' are treated, namely coercive and benevolent leadership on the one hand, and collective action in the sense of joint leadership on the other hand. Finally, future leadership constellations and the quest for international order are discussed.
\end{abstract}

[Page 35]

Journal of World-Systems Research

\section{Zusammenfassung}


Der Artikel führt das Konzept der Hegemonie in die Leadership-Theorie ein, die ursprünglich als Kritik an der Theorie hegemonialer Stabilität entstand. Es macht jedoch Sinn, die zwei Theorien auf der Grundlage einer Konzeption der Akteursgröße innerhalb der neoliberalen Internationalen Politischen Ökonomie zu kombinieren. Ausgehend von der These des Neo-Institutionalismus, daß die Existenz eines Hegemons keine notwendige Bedingung für die Produktion öffentlicher Güter ist, wird mit Hilfe der nichtkooperativen Spieltheorie gezeigt, wie verschiedene 'leaders' gemeinsam öffentliche Güter produzieren können. Darauf aufbauend wird ein spieltheoretisches Modell entwickelt, welches Nash-Gleichgewichte benutzt, um die Bedingungen zu illustrieren, unter denen es für ein Hegemon rational ist, für gemeinsame 'leadership' zu optieren. Gleichzeitig wird verdeutlicht, warum 'followers' rational ihr Trittbrettfahren einstellen und sich an der Bereitstellung der öffentlichen Güter beteiligen. Dies führt zur Ausprägung von multiplen Gleichgewichten. Die Akteure finden sich in einem Koordinationsspiel, in dem sie jeweils unterschiedliche Gleichgewichte und damit auch unterschiedliche individuelle Strategien präferieren. Der Konflikt entsteht an der Frage, welche Akteure sich 'after hegemony' an der Produktion der öffentlichen Güter beteiligen. Dabei sollte zwischen wohlwollend und zwangsgestützten 'Joint-leadership'Systemen einerseits und impliziten gemeinsamen Aktionen andererseits unterschieden werden. Abschließend werden mögliche, vom Modell nahegelegte, künftige Leadership Konstellationen und die sich daraus ergebende internationale Ordnung diskutiert.

[Page 36]

Journal of World-Systems Research

\section{Introduction ${ }^{1}$}

Hegemonic stability theory has over the last two decades emerged as one of the predominant theories within international relations theory and international political economy. Briefly, it holds that a dominant actor uses its power to create international economic regimes, most notably the International Monetary Funds in finance and exchange-rate politics, and the General Agreement of Tariffs and Trade. Drawing on the theory of public goods, the hegemonic stability theory argues that only a dominant actor, a hegemon, has the interest and capacity to maintain the stability of an open international economic system (Kindleberger 1976; Keohane/ Nye 1977: 44). Stated boldly, the advocates of the theory assume that a single hegemonic power create s a stable international economic order by providing international public goods. The theory also asserts that the decline of the hegemon leads to global economic instability and to regionalization of international economic affairs (Kindleberger 1986).

[Page 37]

Joumal of World-Systems Research 
Hegemonic stability theory has also received criticism for its various limitations, such as limitations in the applicability of the public-goods hypothesis. Critics suggest that collective action on the part of small groups in the international system may be possible (Snidal 1985a; Gowa 1989: 307) and argue that the provision of openness and stability in the world political economy implies the supply of excludable rather than public goods (Conybeare 1984). In both respects it is crucial to note that there are different versions of hegemonic stability theory. Keohane (1980) and, in particular, Lake (1993) have distinguished between a deterministic theory of hegemony and a far less deterministic leadership theory. The crucial point separating both theories is the possibility of international cooperation, defined as change in the behavior of actors in response to the actual or anticipated preferences of other actors through a process of policy coordination (Keohane 1984: 51; Milner 1992: 467). The distinguishing feature between hegemonic and leadership theory lies in their explanation of international stability and international institutions. While hegemonic theory relies upon power differences, neoliberal cooperation theory considers international regimes constituted by international cooperation.

This article illustrates the possibility of introducing a concept of power and the notion of hegemony into leadership theory, thus uniting a couple of previously competing perspectives. Most important, in applying game-theoretic models, the article both rationalizes the strategic shift of followers from free-riding to taking part in leading, and shows the exact sense in which interaction between leaders occurs. In the international relations literature, several simultaneous leaders are often referred to as cooperating, while cooperation is defined as the adjustment of policies between several countries. However, not to obfuscate matters unnecessarily, we try to avoid the term since game theory distinguishes between cooperative and non-cooperative games. We make no reference to cooperative game theory. If two or three actors are all adopting a strategy of leading, they do not do so because of binding agreements but because this const itutes a Nash equilibrium in a non-cooperative game. Subsequently, we discuss the nature of conflict in joint-leadership models, stemming from the second-order problem of which actors contribute to the production of the public good. The main objective of this article is to show how various kinds of games between a hegemon and followers or between a group of leaders can be used to describe the changing structure of postwar international political economy, distinguishing between different epochs, 1945-1950, 1951-1970, 1971-1995.

[Page 38]

Journal of World-Systems Research

Section 2 provides background material, introduces the theory of hegemonic stability, focusing especially on the concept of public goods in international political economy, and discusses briefly its neoliberal critique. Section 3 presents a game-theoretic model of hegemony and joint leadership. Section 4 analyzes the model, illustrates the changing equilibria in postwar world politics, and discusses the United States' hegemonic decline 
and the emergence of joint leadership. Section 5 considers further implications of parametric changes within the model. Section 6 discusses coercive and benevolent hegemony and leadership. Section 7 provides an exhaustive characterization of all possible equilibria given the three strategies hegemon, leader, follower for different costs of producing the public good. Section 8 evaluates the prospects for prediction and the quest for international order.

\section{$\underline{2}$ The Theory of Public Goods in International Political Economy}

For more than three decades since the publication of Morgenthau's seminal work Politics among Nations (Morgenthau 1948/1973), the dominant theory of international relations, realism, was based on the assumption that international politics takes place within the shadow of war (Aron 1962: 6). The anarchical international system and especially the absence of an authoritative government creates a permanent threat to all countries, which have to rely on the means they can generate and the arrangement they can make for themselves (Waltz 1979: 111). Therefore, to ensure their survival and independence in the long run, countries have a predominant interest in avoiding a loss in their relative capabilities even in the short run. In consequence, realism argues, economic well-being is not the prime interest of countries. Only if their survival is assured can countries seek other goals among which welfare holds a prominent role (Carr 1946: 145; Waltz 1979: 126; Grieco 1990: 39).

[Page 39]

Journal of World-Systems Research

Arguing from these points of view, realism postulates a mercantilist world economic system as a natural consequence of international politics. While seeking to avoid relative losses, countries turn out to be anxious about the distribution of benefits and they are therefore very pessimistic about the possibility of international cooperation. Nevertheless, cooperation is considered a necessary condition for the existence of a liberal international trading system. A liberal international economic order presupposes the joint and, to some extent, coordinated political action of countries.

The resulting gap between realist expectations and the observable reality of postwar economic politics was not discussed until Charles Kindleberger (1973) analyzed the great depression and concluded that there is a crucial relationship between global economic stability and the existence of a single leader, a country which provides international public goods. Public goods are the kind of goods where exclusion of consumers is impossible and consumption by one actor does not exhaust its availability for other actors. In international economic affairs an open trading system, well-defined property rights, common standards of measures including international money, consistent 
macroeconomics policies, proper action in case of economic crisis, and stabilized exchange rates[2] are said to be public goods (Kindleberger 1981).

[Page 40]

Journal of World-Systems Research

It is not surprising that the foundations of the 'theory of hegemonic stability' were developed by an economist. Ever since David Hume the economics profession has been fully aware that a liberal international economic order is in the interest of all countries. However, the theory still breaks with classic liberal political economy (Frey 1984: 1520 ). Countries may prefer protectionism if other countries do not reciprocate. David Ricardo's theorem of comparative advantage argues that free trade is in the interest of countries even if other actors do not liberalize their trade regimes. The theory of hegemonic stability is not a liberal theory in the sense of neoclassical economics. All the same, it is less mercantilistic and therefore closer to the liberal economic tradition than realism had been before. Furthermore, the notion of free trade being a public good is nowadays much more plausible than Ricardo's theory, which assumed capi tal to be nationally bounded.

The idea that a liberal international economic order is based on reciprocity is crucial for the analysis of international political economy. If we assume, contrary to Ricardo, that the reciprocal structure is considered a fair approximation of the world economy, then it follows that a common interest in an open and stable world economy does not necessarily lead to the provision of public goods since all actors have an incentive to free-ride (Olson 1965). The public-goods analys is of international political economy gained prominence parallel to the ascent of regime analysis. Regimes, international institutions, and the decision-making procedures which led to them, have been considered to serve the interest of all countries. However, in the absence of external enforcement, countries are reluctant to negotiate international regimes since all actors have an incentive to free-ride. Stated game-theoretically, defection is the dominant strategy of countries.

[Page 41]

Journal of World-Systems Research

As Mancur Olson has argued, the probability that public goods (including those constituting a liberal international economic order) will not be provided is high, if the number of actors is large. According to Olson, one way to solve the problem is to introduce selective incentives. If a 'private good' is unavoidably linked to the public good, the latter may result as a by-product. Another explanation of the origins and persistence of collective action emphasizes the role of a dominant power [3]. Early contributions to this theory (Wagner 1966; Breton/ Breton 1969; Frohlich/Oppenheimer/ Young 1971) 
were appreciated by Olson (1971), but considered valid only if the imagin ative leaders were to find selective incentives:

A leader or entrepreneur, who is generally trusted (or feared), or who can guess who is bluffing in the bargaining, or who can simply save bargaining time, can sometimes work out an arrangement that is better for all concerned. . . There is no certainty, and often not even a presumption, that an entrepreneur will sometimes be able to work out an arrangement that is agreeable to the parties concerned. . . When the group in need of a collective good is sufficiently large, an entrepreneur cannot possibly provide an optimal supply of the good through bargains or voluntary cost-sharing agreements with those in the group. (Olson 1971: 176-177)

Mancur Olson and Richard Zeckhauser argue in their economic theory of alliances that in the provision of collective goods there is a tendency for the largest member to bear a disproportionately large share of the costs (Olson/ Zeckhauser 1966). Natural leaders gain more from the provision of public goods and they place a higher absolute value upon it. Likewise, it can be argued that hegemons are more interested in international economic stability and openness and will therefore construct international regimes serving this end.

Even though hegemonic theory originated in the work of an economic historian, it is nevertheless hardly surprising that realism has adopted the power-based theory of public goods with only slight differences. Most important, political scientists argue that hegemons create liberal international economic orders not from altruism but from their own self-interest in open markets (Stein 1984: 357). According to Robert Keohane (Keohane 1980; Keohane 1984: 31) two statements are central for the realist theory of international stability: First, order in world politics is created by a single great power, a hegemon, who will stabilize the world economy (Kindleberger 1973: 305; Krasner 1976). Second, cooperation, the mutual adjustment of policies, depends on the perpetuation of hegemony, since the dominant power must enforce the rules and institutions.

[Page 42]

Journal of World-Systems Research

Deviating from Mancur Olson's formal theory, realism assumes different constraints and capabilities of actors (Kindleberger 1976: 57). Countries simply differ in power, size, and wealth, and they therefore have different interests. How countries choose between their options depends strongly upon their position within the international system (Krasner 1976). This position is determined by economic factors such as availability of capital, the size of the internal market, and a competitive advantage in the production of manufactured goods. To be considered hegemonic, a country must have access to crucial raw material, control major sources of capital, maintain a large market for imports, and hold an absolute advantage in the production of advanced goods and services (Keohane 1984: 33). 
From time to time through history, a hegemon emerges (Kennedy 1987) which has a strong incentive and the capabilities to produce a liberal world economic order. Since the hegemon has efficient production capabilities, the dominant power will be the primary beneficiary of a free international economic system (Wallerstein 1980: 38). More importantly, the hegemon also has the ability to 'punish' defectors (Alt/ Calvert/ Humes 1988: 446). If the dominant power also desires an open world economy, this power accepts its hegemonic role and stabilizes international economic relations and coerces other countries, i.e. followers, to open their economies as well. The hegemon might also tolerate the free-riding of small countries (Kindleberger 1976: 19). Therefore, the theory of hegemonic stability rests on a simple causal relationship, namely that a liberal and stable world economic system requires a single great power (Kindleberger 1973: 305). Consequently, if no hegemon exists, the public good of international economic stability will not be provided.

[Page 43]

Journal of World-Systems Research

This argumentation was challenged by the neoliberal theory of international cooperation, namely by Duncan Snidal (Snidal 1985a). Following Robert Keohane's After Hegemony (Keohane 1984), Duncan Snidal argues convincingly that a small group of cooperating actors, what we refer to as 'joint leaders', can replace a hegemon, thus jointly providing international public goods. Openness, therefore, can arise or be maintained in the absence of a hegemon. Leadership theory, as David Lake (1993) coined this research program, is able to argue, without referring to hegemons, that joint leaders may provide international public goods. Countries are able to adjust their economic policies through a process of policy coordination. The problem that countries face in regard to the production of stability and wealth in the world political economy is dominantly expressed by the prisoners' dilemma (Conybeare 1984), which is considered to resemble the logic of collective action (Brams 1975: 144; Taylor 1976: 17-25; Hardin 1982: 25-30, Morrow 1994b: 281).

For Conybeare, the analytical shift from pure public-goods theory to the prisoners' dilemma is crucial since he denies that free trade, for example, is a public good. First, he stresses that the principle of non-excludability is not given. Countries may hinder economic subjects from one particular country from entering their markets. Tariffs and even more so quotas can be employed against different actors to quite different extents. Secondly, Conybeare points out that there is rivalry in the consumption of the benefits from free trade (Conybeare 1984: 9). It is therefore, as Timothy McKeown puts it, "not very sensible to view the international system as isomorphic with an economic system of perfect competition" (McKeown 1983: 78).

[Page 44]

Journal of World-Systems Research 
The possibility of monitoring the behavior of other actors and the resulting rivalry and excludability explain not only that the burdens of providing a public good can be shared; they also make clear that the benefits from an international public good may not be equal. This is crucial since it is quite common to assume that larger countries in general gain more from an open world economy than small countries do (although other factors such as the [export+import]/GDP ratio also play a role). Therefore, one should expect that larger countries have a higher incentive to invest in international openness (Krasner 1976: 322). However, by trying to maximize its own payoffs, a hegemon serves the benefits of other countries, and international public goods might be created as a by-product of the hegemon's production of private goods (Russett 1987: 222).

The problem Conybeare refers to depends heavily on the dichotomous notion of goods being either purely public or purely private. Conybeare is correct in stating that a liberal economic order and international economic stability are not pure public goods, but neither are they pure private goods [4] In all cases but monetary affairs the possibility of excluding single actors exists. However, this possibility is costly, for example in regard to the monitoring of norm-deviant behavior and to enforcement measures. Quite different from the production of private goods, the exclusion of other actors requires a political act. Therefore, the definition of a collective good in the narrow sense is not met. On the other hand, without costly discriminatory measures, openness and stability come close to resembling public goods. Moreover, if the enforcement of a cooperative agreement is costly (Oye 1985: 15), the policy measures themselves become a public good (Gowa 1989: 315$)$.

It is currently undisputed that the connection between hegemony and openness in the world economy is more complex than previous contributions to the theory have so far considered. But it is also widely appreciated that an interrelation between power distribution and the maintenance and creation of international institutions does exist. Therefore, the hegemonic and the leadership strands of argument about international economic stability are not necessarily in competition. The present article shows that they are easily and fruitfully linked if one presupposes both, that is both the possibility of a hegemon as well as several joint leaders. In this regard we distinguish between hegemonic and leadership provision of public goods. Joint leadership between two or several large powers is possible, but unilateral, hegemonic provision of international public goods demands less transaction costs and will pay off for all actors under certain circumstances.

[Page 45]

Journal of World-Systems Research

More important, the following game-theoretic model develops simple explanations, illustrating how and why a hegemonic system turns into a joint-leadership system. It 
indicates the conditions which presuppose unilateral or collective action. In addition, we discuss the consequences of joint-leadership systems in general, pointing out the relevance of disagreement and political struggle among second-dominant powers, namely the EC and Japan, over the participation in covering the cost of producing international public goods. These aspects, which resemble either a battle-of-the-sexes or a coordination situation, are ignored in the dominant prisoners' dilemma model of international politics, which focuses on commitment, enforcement and strategic interaction.

[Page 46]

Journal of World-Systems Research

\section{$\underline{3}$ A Game-Theoretic Model of Hegemony and Joint Leadership}

Game theory, or more specifically non-cooperative game theory, provides a powerful tool for the analysis of international affairs since strategy is the essence of politics. The strength of game theory involves focusing on strategic interaction between two or more players, where each player has a set of strategies available, and where the payoff to each player depends on the strategies chosen by all the players. Contrary to play against "dead nature," where a player maximizes his payoff in a given, fixed environment, in game theory each player seeks to maximize his payoff given that all the other players also seek to maximize their respective payoffs. Hence in an $n$-player game, we get $n$ simultaneous maximization problems to solve. The most famous and frequently used solution concept in game theory, which we will also use in this article, is the Nash equilibrium. A Nash equilibrium is a state of affairs where no player has an incentive to deviate unilaterally from his chosen strategy. That is, he can not improve his payoff by deviating unilaterally. Hence we also have an equilibrium e.g. if two players can both improve their payoffs by deviating in a certain manner, while a third player receives a lower payoff. In noncooperative game theory, binding agreements between the players are thus not allowed. Each player seeks instead to maximize his own payoff disregarding the payoffs others receive. There are frequently more than one equilibrium, and the players typically have different preferences between these, and try to coordinate on one they prefer. Which equilibrium is chosen may depend on historical precedent, framing effects, saliency, anchoring and adjustment procedures, etc. In world politics and international political economy game theory is used to illustrate the structure of decision-making of countries confronted with collective dilemmas. Unfortunately, game theory very seldom takes into account that actors differ. The game-theoretic approach to international politics has been restricted to equal-actor games and treats, as Duncan Snidal puts it, "very large and very small ones as equal partners in a prisoners' dilemma" (Snidal 1985b: 47). As a result, its direct usefulness to the analysis of international relations and more particular to the analysis of the consequences of power distribution is limited. This restriction obviously limits also the game-theoretical analysis of hegemonic decline. Furthermore, it is quite common for international-relations theorists to restrict game-theoretic models to their 
simplest form, namely $2 \times 2$ matrixes. To illustrate the concepts of hegemony, free-riding, and joint leadership, however, a more complex model is required. We present in this section five assumptions underlying the model and the model itself, which is able to illustrate much more than previous models how a decline in interest in international public goods leads to an increase in joint action. The hegemonic decline of a leading actor, therefore, should lead to more 'cooperation' as this phrase is used in international relations theories. In section 4 we analyze the implications of changing the one variable in the three-actor model, namely the size of each country, and in section 5 we discuss the implications of changing four parameters in the model, namely production costs of public goods, transaction costs, and the sharing rules of the hegemon and of the leaders.

[Page 47]

Journal of World-Systems Research

We use size to reflect a country's interest in stable international economic relations. Even though small countries may profit more in relative terms, larger economies import and export more in absolute terms and they also participate more in the production of international liquidity. The interest in international public goods and the gains from the provision of these, therefore, depends to some extent on relative size.

In order to keep the model as simple as possible, we introduce a $3 \times 2 \times 2$-model which is based on the following five assumptions:

\section{Assumption 1}

Public goods are produced if a minimum of either one hegemon or two leaders exist. [5]

This is a rigid assumption and it may seem to be implausible. But since we introduce this assumption to a three-actor model, it can be reformulated so that contribution to covering the costs by a suitably chosen majority of the actors involved leads to the production of international public goods.

\section{Assumption 2}

Only the US has so far been capable of acting as a hegemon. The EC and Japan can at most act as leaders. Therefore, the US has three strategies: to act as hegemon $(\mathrm{H})$, to lead (L), or to follow (F). The EC and Japan can either lead (L) or follow (F).

\section{[Page 48]}

Journal of World-Systems Research 
The literature holds that only the largest countries are willing to act as hegemons (Lake 1984: 150). The model allows for the assumption that either the EC or Japan acts as a hegemon. However, the model also indicates that this will lead to huge losses, which can be referred to as 'imperial overstretch'. To keep the model as simple as possible, we have opted for a $3 \times 2 \times 2$-matrix instead of a $3 \times 3 \times 3$-matrix, assuming that only the largest actor can be a hegemon. In the general analysis in section 7, the EC and Japan are also allowed to be hegemons.

\section{Assumption 3}

There is costly excludability of consumption. However, countries with 'larger economies' are likely to receive a higher payoff from the consumption. We roughly indicate the payoff from the consumption as the size of a country's economy relative to the aggregated size of the OECD economies, that is us/oecd, ec/oecd, and $\mathrm{j} / \mathrm{oecd}$.

\section{[Page 49]}

Journal of World-Systems Research

The empirical relevance of this assumption is open to discussion, though we consider it to be an approximation to reality. For any model a tradeoff has to be struck between simplicity, generality, empirical support, etc. Using the empirical data available today, it is not clear that an alternative to assumption 3 is more appropriate, because a multiplicity of other factors interact in many different directions. In the light of this, there is virtue in simplicity. However, it is important to note that assumption 3 can be varied in any way for which one might find an argument or empirical support without altering the deeper nature of our argument presented in this article. Assumption 3 nevertheless needs a few comments. Competing concepts would argue that it is not size but world market integration that is causing an interest in a stable and open world economy. In this regard, there are both a relative and an absolute measurement of world market integration. The relative one is called openness and is calculated as exports plus imports divided by the countries nominal gross domestic product. This assumption would lead to the hypothesis that highly specialized and small countries like Sweden (which has an export/GDP ratio about five times that of the US), Taiwan, and Korea have a larger interest in stabilizing the liberal world economy than large countries such as the US and Japan. The absolute indices of world market integration are simply exports. Countries which export more goods and services have an higher interest in a liberal trading system. Again, there are good reasons to doubt this. Countries with a highly specialized export industry that has a world market monopoly have no interest in open trading structures since they are able to sell their goods anyway. The oil-exporting countries are a good example for this case. Furthermore, even if we consider exports as the basis of an interest in international public goods, the US, EC, and Japan can be considered the dominant actors. The only difference would be that the three actors are more similar, which leads to political results that we discuss in more detail in sections 7 and 8 . There may be a better measurement of the 


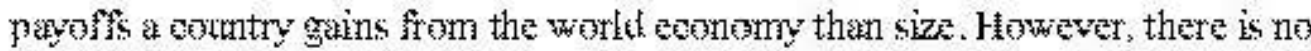
obvioutsy better, simpler way to meastre this.

\section{Lwampiton 4}

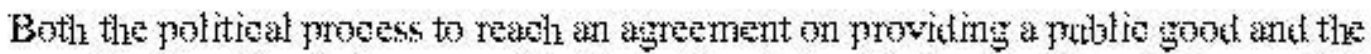

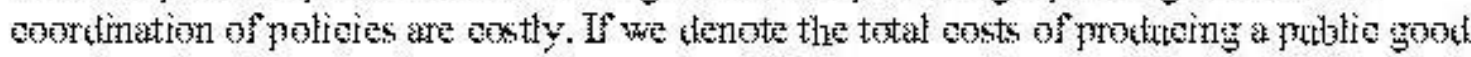

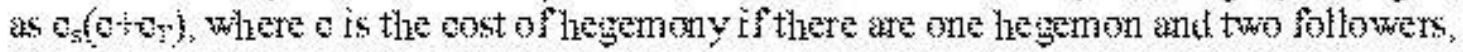

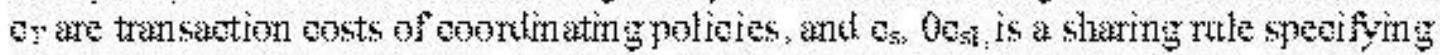
what fration of the oosts each ador ineurs. The transation costs are then 6 y=0 if the

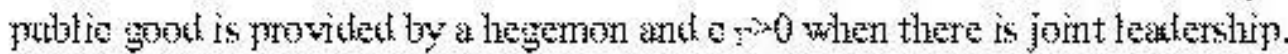

[Page 50$]$

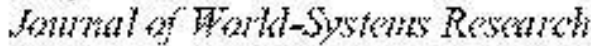

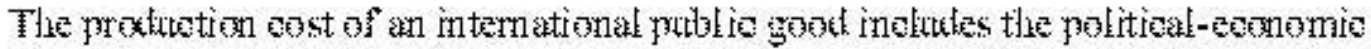

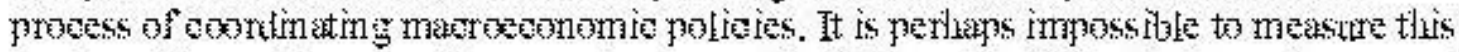
oost exacty; ant it may make sense to assume that this cost is thigher in the early yeas of an intemational regime than in later ones. I However, intemational regimes to not work

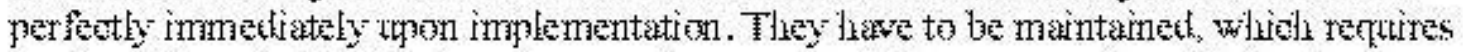

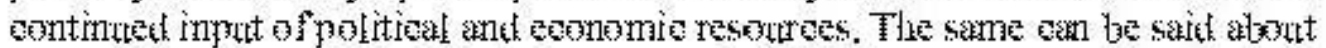
transadion oosts, wididi induke the oosts of reading an agrement, the oosts of monitoring the politioal ation of oognerative adors, and the oost of agree ing to maintain an intemational regime.

\section{Aximmpiton 5}

A follower toes net take part in oovering the oost of yroktuing the problic gookt.

This is self-evitient sinee a free-riter thes net change its polieies but rather gains from the polioy thanges of other adors.

Let th astume for expositional onvenienee linearly increasing transiation oosts,

$$
c_{T}(h+1)=a(h+1-1) \text { for } h+1 \geq 1 \text {, }
$$

where $h, h=0,1$, is the number of hegemons $l, l=0,1, \ldots, 3-h$, is the number of leaters, and a is a parameter [9. This means that the more adows are involvet, the more tifletent it is to reach an agrement ant the higher ate the monitoring oosts. Jenez it is easier to integrate a limited number of similat owntries than to integrate the wert keonemy.

[Page 51]

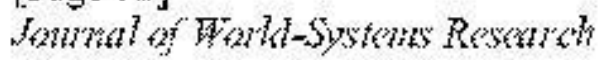




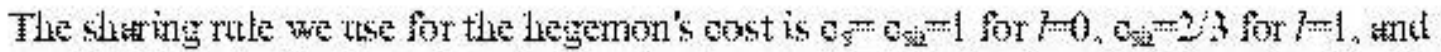

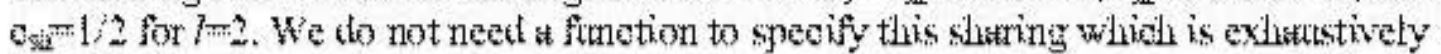
described in the grevious sentence. However. in orter to woodent more conveniently for the sluaring in our model, let us dhoose a function that goes through these three points. An ayproyrate function is

$c_{s h}(H / h=1, l)=\frac{1}{12} l^{2}-\frac{5}{12} l+1$

whide atlows for the possible joint yresence of a hegemon and one or two leaters. We refer to this constellation as coereive hegemony, whide we tisetss in further tetak in sotion 7. Briefly, obereive hegemony re fers to an intermediate politiont constellation betwe en yure hegemony and joint leadership, and thes introdtwes the possibility that a Legeman may arge followers to bear some production oosts of the international putblis good.

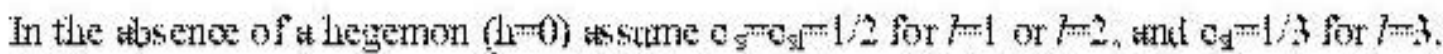

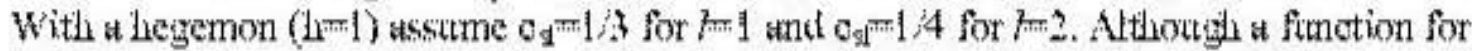
$\mathrm{O}_{d}$ is not necessury either, let ths, consistently with equation (3.2), dhoose one that goes throngl the desired points, viz.

$c_{s l}(L / h, l)=-\frac{1}{12} l^{2}(1-h)+\frac{1}{4} l\left(1-\frac{4}{3} h\right)+\frac{1}{3}$

Strmming xp, if there is a benevolent hegemon, it beats all the oosts. If the hegeman thres followers to participate the hegemon beas twice the oosts of ead leater. If there

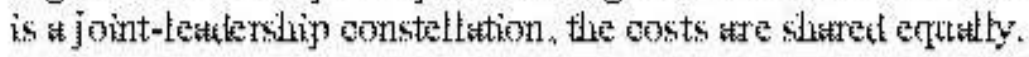

[Page 52]

Jammal of Wtall-Systems Reswath

The payoff for being a Leigemon is

$P(H / h=1, l)=10 \frac{\text { country }}{\text { oecd }}-c_{s h}(H / 1, l)\left(c+c_{T}(1+l)\right)$,

where we mattinty by 10 to get conveniently sized payoffs.

The payof for being a leater is 


$$
P(L / h, l)=\left\{\begin{array}{l}
10 \frac{\text { country }}{\text { oecd }}-c_{s l}(L / h, l)\left(c+c_{T}(h+l)\right) \text { if } h=1 \text { or } l \geq 2 \\
-c_{s l}(L / h, l)\left(c+c_{T}(h+l)\right) \text { else. }
\end{array}\right.
$$

The payof for following is

$$
P(F / h, l)=\left\{\begin{array}{l}
10 \frac{\text { country }}{\text { oecd }} \text { if } h=1 \text { or } l \geq 2 \\
0 \text { else }
\end{array}\right.
$$

Obionksty, it is more expensive to ad as fegemon than to ad as a leaker, And it is more

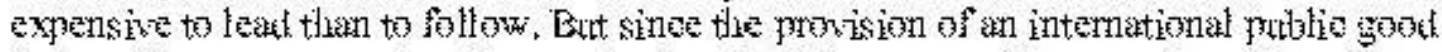
is a positive-scm gente for all corntries involvat, it may pay for oorntries to be a

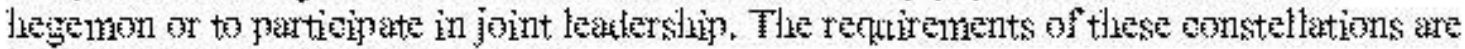
diseussed in the following seetions.

\section{Analysis of the Model}

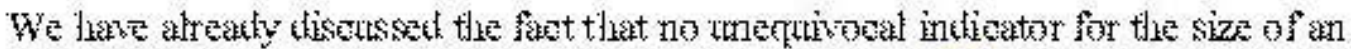

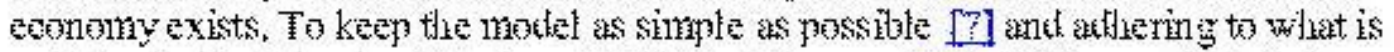
common in the literature (Krasn er 1976; Kintletererger 1981: 249), we estimate the interest of owtuntries in an open ank stable workt econonny acoorting to tweir sizz. We lay

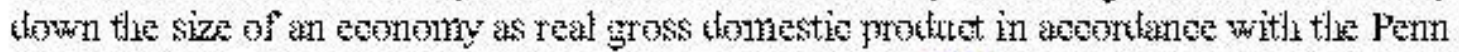

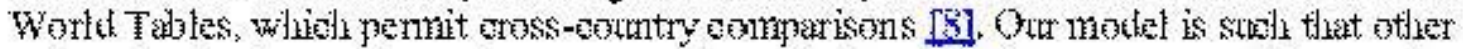
values for the sizes of the various econminies, and also other factors not pertaining to size,

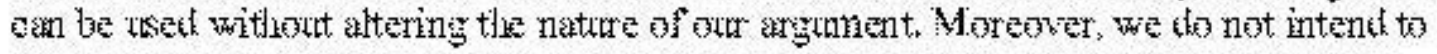

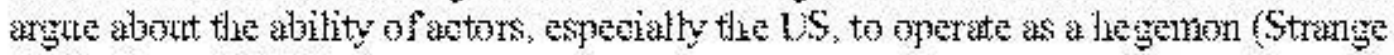
1987 ; Russett 1987).

\section{[Page 53]}

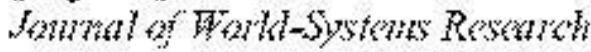

In this section we will andize the mokel choosing parameters for which we believe there

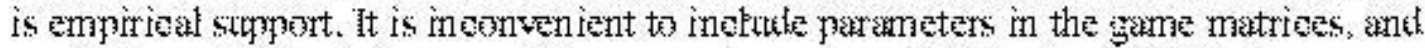
speeifying within what ranges of the parameters we get different equilibria, beearse stoh an andivsis will be dose to meandable. The chosen parameters and weights of the various terms in equations (3.4)-(3.6) is of importanee. These matter not in their absolute values,

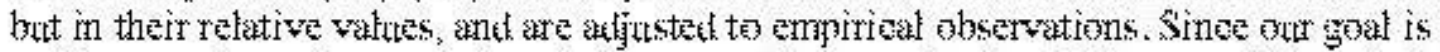
to illustrate that a change in the relative ador sizes may leat to different equilibria, it is 
onvenient to keep the other parameters onstant in the andasis the exat level of these parameters is secondary. However, dhanging these parameters af ets the analysis. Henoz in sedion 5 we disens impliations of parametric dhanges within the medel, and in

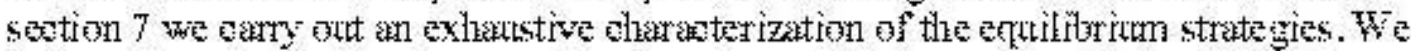

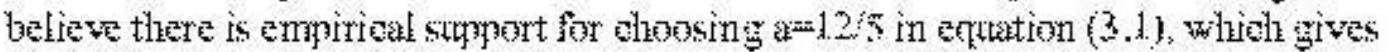

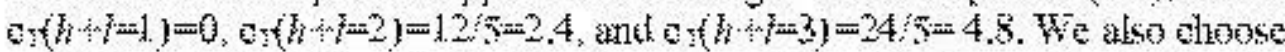

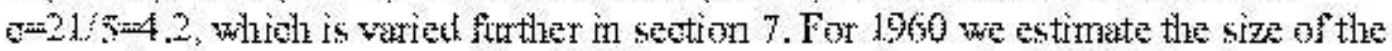

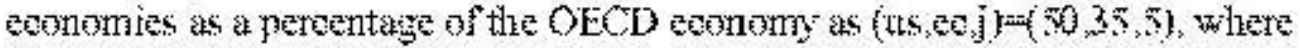

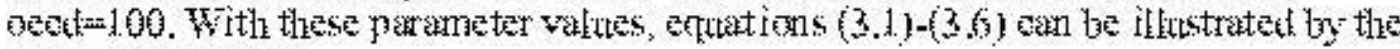
grame in 1 salo 4.1 .

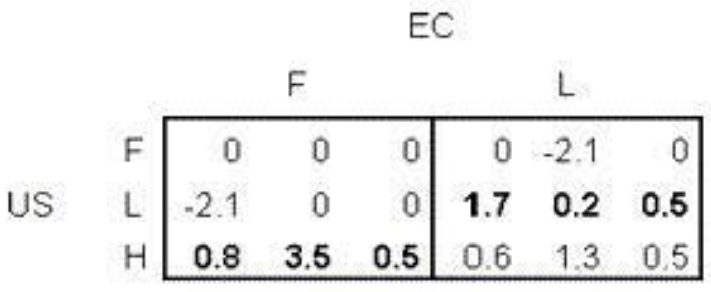

Japan follows

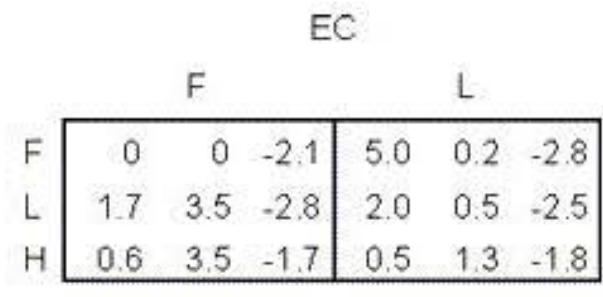

Japan leads

Table 4.1 The game in 1960 with $c=4.2$

[Page :4]

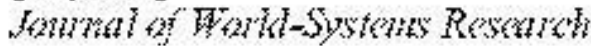

Talole 4.1. has two Nasli equilitria in fure strategies, viz $[\mathrm{F}, F, F]=[0.8,3.5,0.5]$ and $[L, L, F]=[1.7,0.2,0.5]$. A situation in which two leakers yrovide the yodje gobk, even if

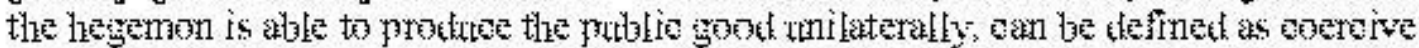

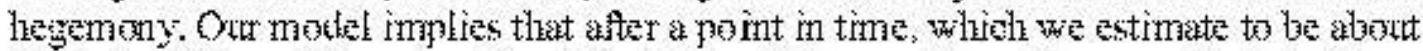
1.950, the LS woukd hewe preferred the latter of these oytions. However, historieally

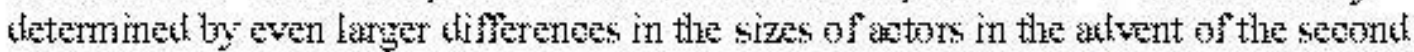
Worlet War, the former has ben chesen, in preferenee to the EC [Q] and Japan. Sine

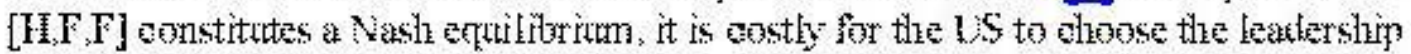

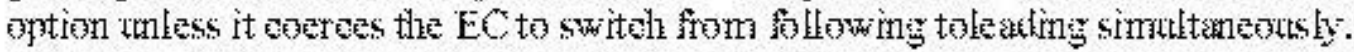
Therefore, a dedining relative atvantage may leat to a political strugge between the lhegeman ank the soond ranking powers even before the hegemonic periok oomes to a deffinite end. Sinee coercion is costly even for a dominant power and more so for a kedining power, the hegemen may opt to ignore the jossibility of coereive burkenslisaring.

\section{[Page 55]}

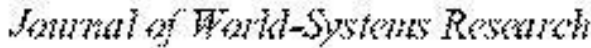


Furthermore, the model also illustrates that the hegemonic strategy $[\mathrm{H}, \mathrm{F}, \mathrm{F}]$ is not just the historical equilibrium but also has a higher 'collective payoff' for all involved. This is a plausible assumption at least for the period from 1945 to 1965 . What is important for the production of order in the international system, since there are just two equilibria and both lead to the production of a public good, is that the public good continues to be provided even though political struggle may occur between the US and the EC over the participation of the latter. Game-theoretically, Table 4.1 illustrates a mixed-motive game where the US prefers the equilibrium $[\mathrm{L}, \mathrm{L}, \mathrm{F}]=[1.7,0.2,0.5]$, the EC prefers the equilibrium $[\mathrm{H}, \mathrm{F}, \mathrm{F}]=[0.8,3.5,0.5]$, and Japan is indifferent toward the equilibria.

For 1975 we estimate the size of the economies as a percentage of the OECD economy according to the Penn World Tables as (us,ec, $j$ ) $=(40,35,15)$, where oecd $=100$. With $c=4.2$, equations $(3.1)-(3.6)$ give the game in Table 4.2 .

\section{[Page 56]}

Journal of World-Systems Research

Table 4.2 has only one Nash equilibrium in pure strategies providing the public good, viz $[\mathrm{L}, \mathrm{L}, \mathrm{F}]=(0.7,0.2,1.5)$ which means that the $\mathrm{EC}$ has an interest in emerging as a leader and accepting part of the cost of producing the public goods, while the US changes from being a hegemon to being a leader. Japan still has a dominant strategy in following. Note that $[\mathrm{H}, \mathrm{F}, \mathrm{F}]=(-0.2,3.5,1.5)$ is no longer an equilibrium as hegemonic leadership becomes too costly for the US. Table 4.2 also has a Nash equilibrium where all actors choose the strategy of following, thus indicating that the probability of the public good being produced diminishes. This situation corresponds to a coordination game between the US and the EC. If the US and the EC agree upon the mutual destructibility of the situation should both opt for following, then negotiations and eventually joint action may be expected to follow. The emergence of an $[\mathrm{F}, \mathrm{F}, \mathrm{F}]$ equilibrium indicates that jointleadership systems are much more vulnerable against instability than hegemonic systems. In cases of emergency or crisis it is not at all clear whether joint action will be achieved. Moreover, a time gap between hegemonic and collective leadership systems should be expected since there is a conflict between the former hegemon and the former follower over the conditions and the distribution of costs between major actors in a jointleadership system. It is at this point crucial that countries learn that structural conditions have changed and that thorough analysis is required.

[Page 57]

Journal of World-Systems Research 


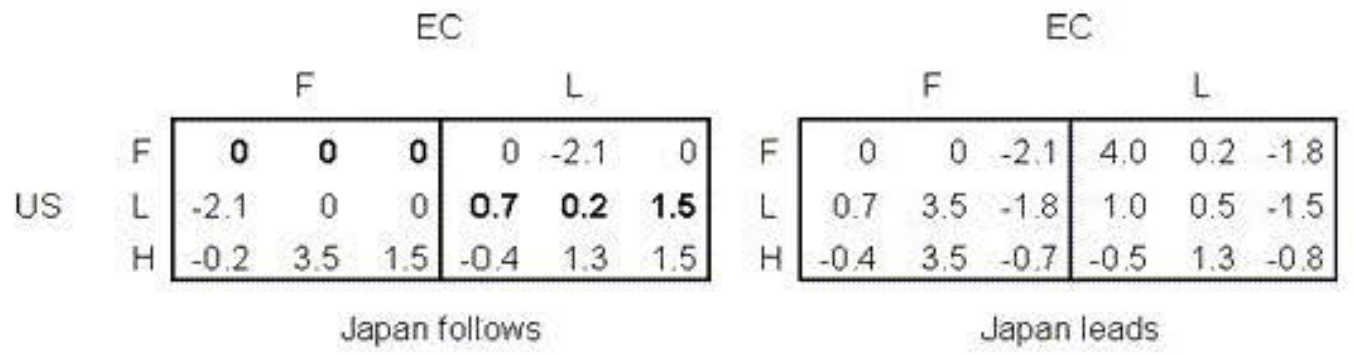

Table 4.2 The game in 1975 with $c=4.2$

The matel tisensed so far has a number of satisfadory implioations, whid in general illustrate the postwar develoyment of intemational politioal economy. Fig. 4.1 shows the

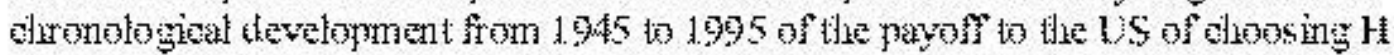

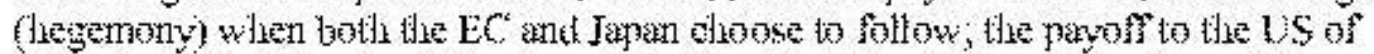
dhoosing L (joint leaterwilig) given that either the EC or Japan dhoose L; and the payof

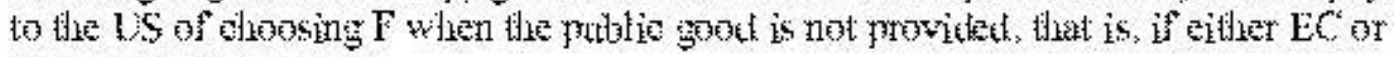
Japan or botls dioose $\mathrm{F}$.

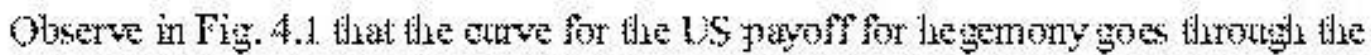
points $(1.960,0.5)$ and $(1.975,-0.2)$, and that the enve for the l.s payol for joint

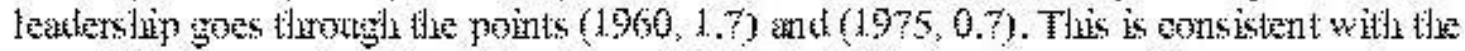

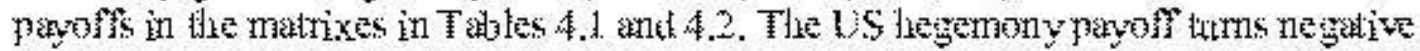

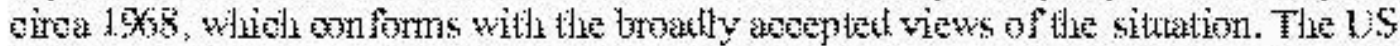

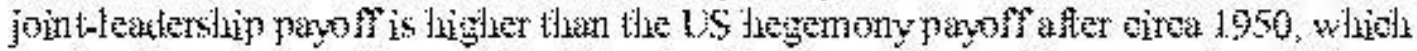

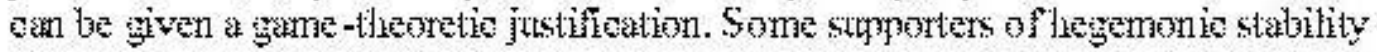

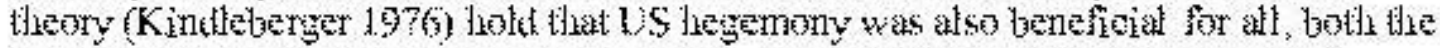

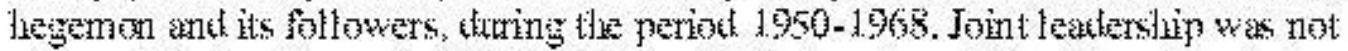

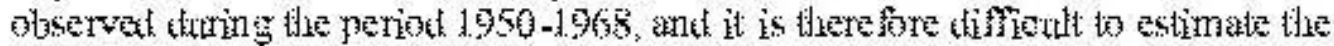

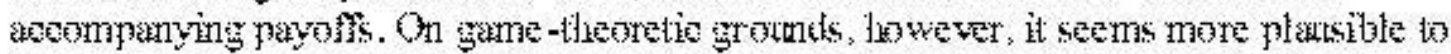

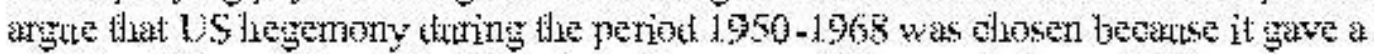

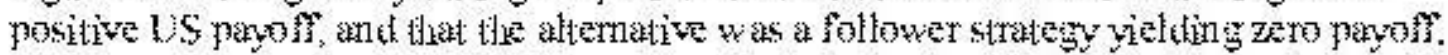

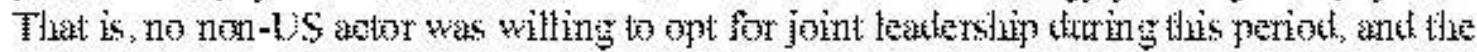

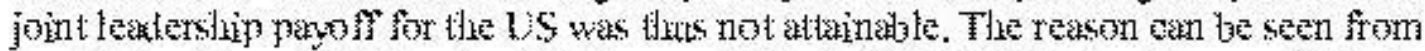

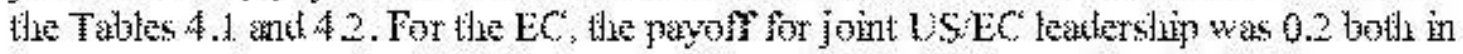
these years, whereas the EC follower payof was $\$ .5$ in 1.960 as well as in 1975 .

[Page 58]

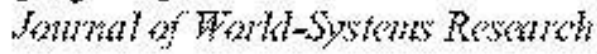




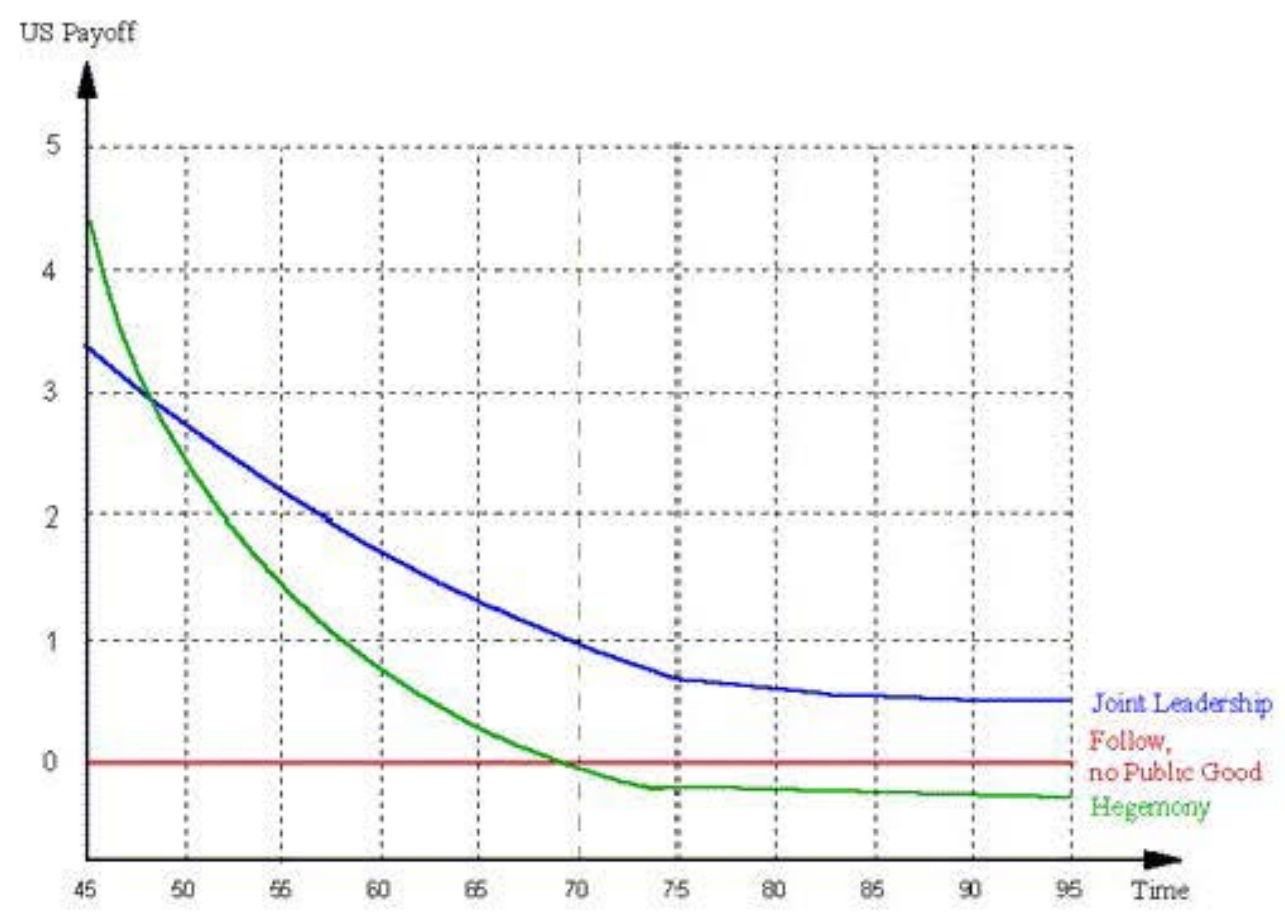

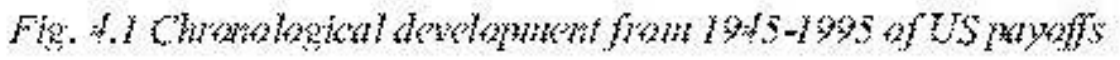

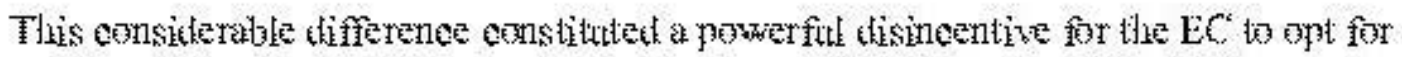
anything other than a follower strategy, leming the buteden to the LS, whids was not eapable of ooeroing the EC into joint leakdersizh. The situration was even more

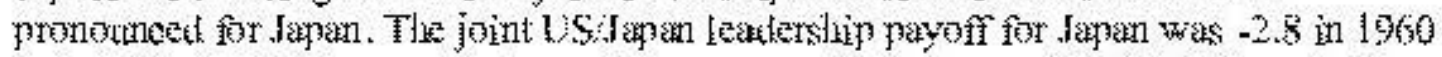

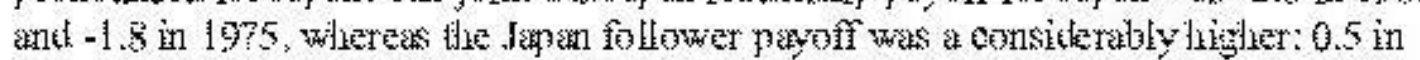

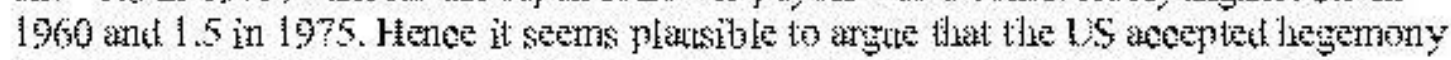

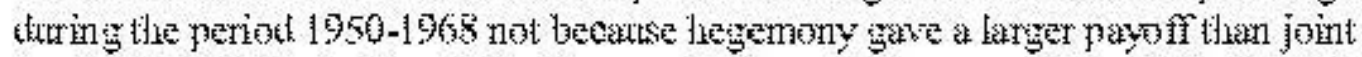

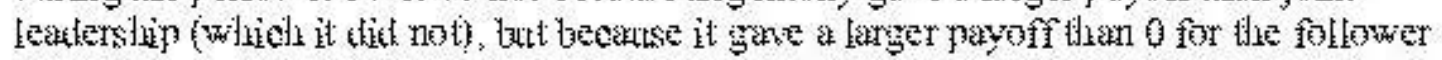

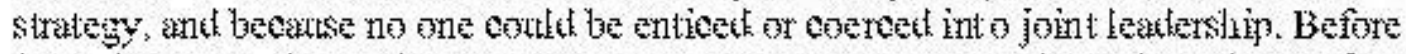

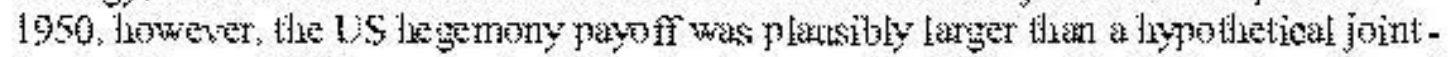

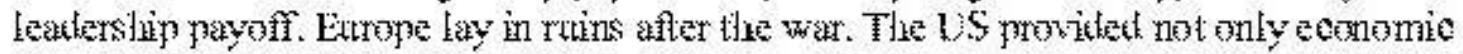

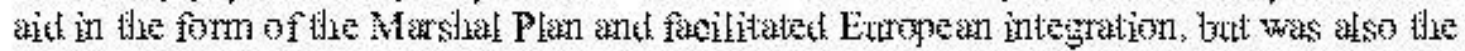

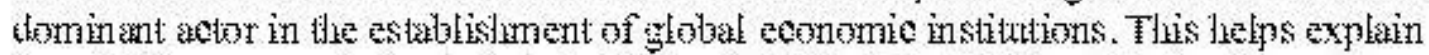

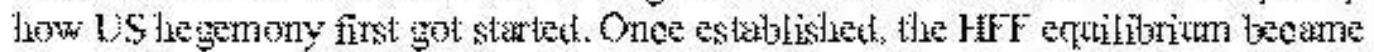
thistorically entrenched and remained for deeates as salkent foeal point (Selhelling 1960 ).

[Page 5]

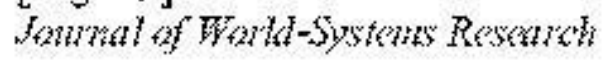


The following sample of $3 \times 2$ models slows the develonment of international postwar politios. In order to explain the oentral findings as simply and familiarly as possible, the

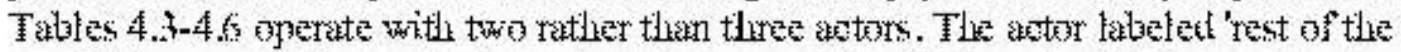
world" does not refer to all other adors in the world as ike from the US, but rather to any actor endowed with sufficient unity and power to dhoose between the two strategies of following and leading. The games are illustrated from the US's viewnoint relative to the rest of the workt, showing the strategie dilemma of a hegemon in dedine and the strategie themma of followers given thegemonis dedine. Con fining attention to the orlinally

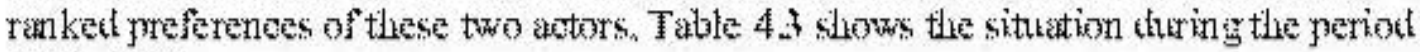
$1945-1950$.

\begin{tabular}{|c|c|c|}
\hline & \multicolumn{2}{|c|}{ Rest of World } \\
\hline & Follower & Leader \\
\hline Follower & 1,1 & 1,0 \\
\hline Leader & 0,1 & 3,2 \\
\hline Hegemon & 4,4 & 2.3 \\
\hline
\end{tabular}

Table 4.3 A simple model of the world political economy, 1945-1950

[Page 60]

Jammal of Whalk-Systems Reswath

\begin{tabular}{|c|c|c|}
\hline & \multicolumn{2}{|c|}{ Rest of World } \\
\hline & Follower & Leader \\
\hline Follower & 1.1 & 1.0 \\
\hline Leader & 0,1 & 4,2 \\
\hline Hegemon & 3,4 & 2,3 \\
\hline
\end{tabular}

Table 4.4 A simple model of the world poltical economy, 1950-1970

Between 1945 and 1950 there was no politioal struggle between the US and other actors over the distribution of oosts in the provision of international miblio goods. Table $4 \mathrm{~A}$ illustrates two equilibria. [HLF] giving $(4,4)$ and $[\mathrm{L}, \mathrm{L}]$ giving $(3,2)$, and the adors easily coortinate on the former. The situation oan be intergreted as one in whided the transation

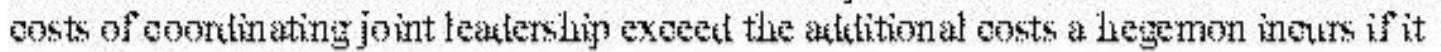
provides the miblie good on its own.

[Page 61]

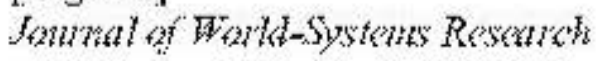




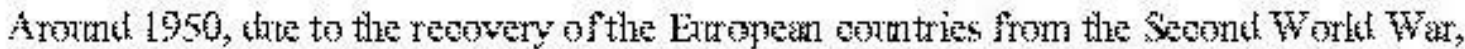

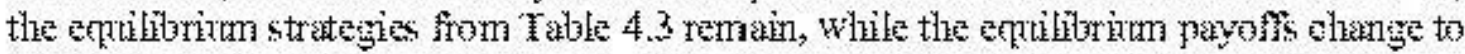
$(3,4)$ and $(4,2)$, as shown in wabe 4 .4. That is, the game dhanges from a oortination

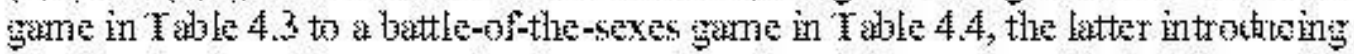

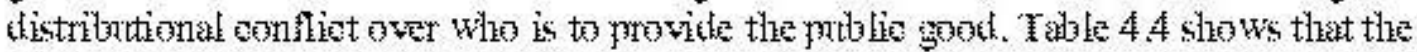

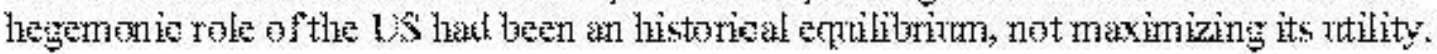

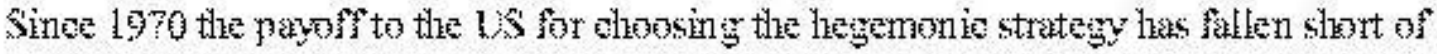

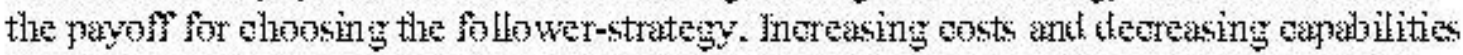

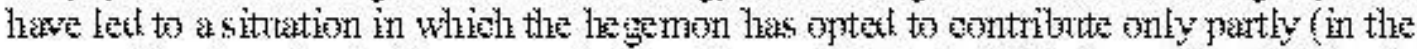
sense of leakling short of hegemony) or not to onntribute at all (in the sense of owllowing,

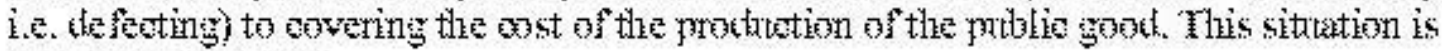
shown in 1 silate 4.5 .

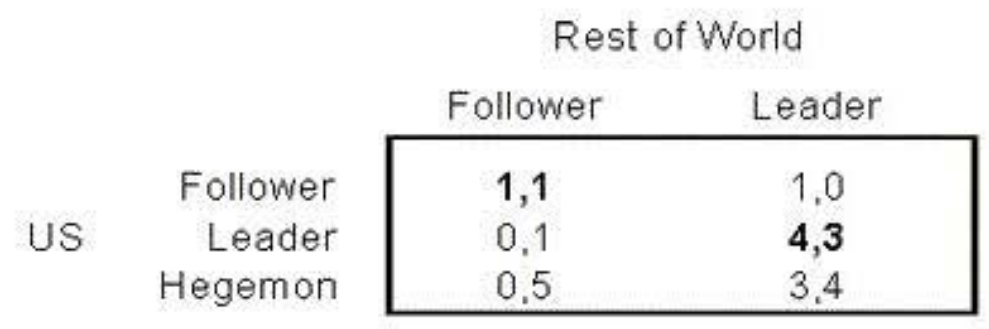

Table 4.5 A simple model of the world political economy, 1971-1995

[Page 62]

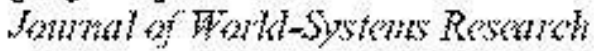

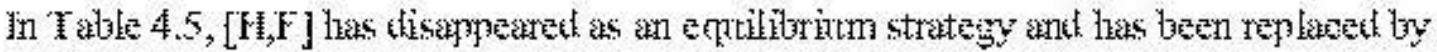

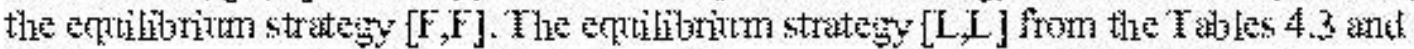
4.4, however, remains. Fenee the battle of -the-sexes sithation in Thale 4.4 has been

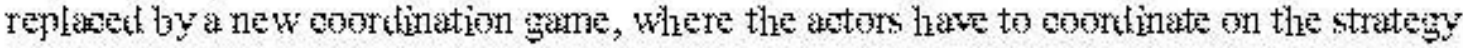
combinations $[\mathrm{F}, \mathrm{F}]$ and $[\mathrm{L}, \mathrm{L}]$. Altherigh the katter might sem most a aryorriate, it took

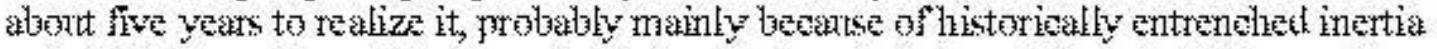
and rigik peraptions of the sidation in international re lations. First, the EC was relatent

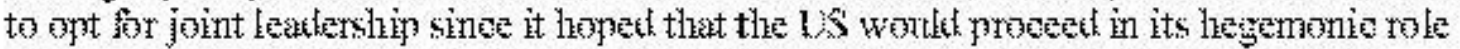

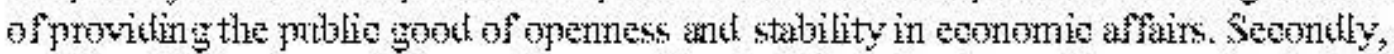

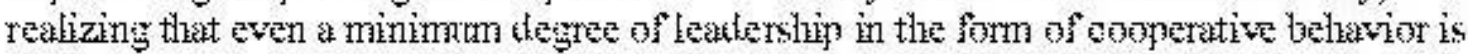

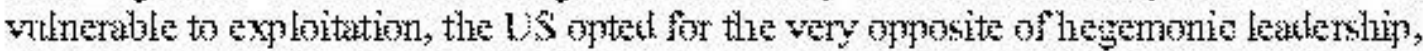
viz a follower strate $y$, yielding the payof $[1,1]$. The $[\mathrm{F}, \mathrm{F}]$ strategy thring the periok $1970-1975$ let, among other things, to the collapse of the bretton Woxk system of fixet

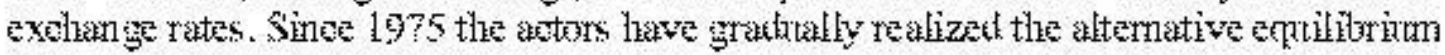
strategies $[\mathrm{L}, \mathrm{L}]$, with the acoompanying payon $(4,3)$, and have stated to explore the varioxts mannes in which this entilituritm oan be realized. 
[Page 63]

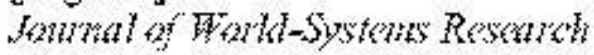

\begin{tabular}{|c|c|c|c|c|}
\hline US & & hegemon & follower & leader \\
\hline EC, JAP & \multicolumn{3}{|c|}{ followers } & leaders \\
\hline results & $(4,4)$ & $(3,4)$ & $(1.1)$ & $(4,3)$ \\
\hline \multicolumn{2}{|c|}{45} & & 0 & \\
\hline
\end{tabular}

Table 4.6 Equilibria from Hegemony to Joint leadership:

A Model of Postwar Developments

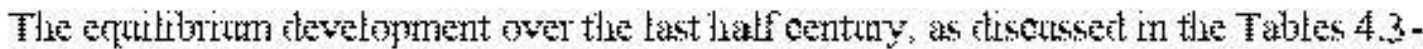

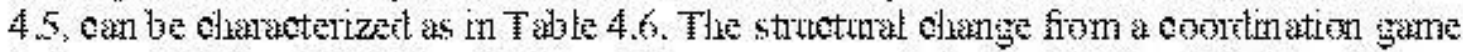
between $[\mathrm{FI}, \mathrm{F}]$ ankl $[\mathrm{L}, \mathrm{L}]$ to a batte-of-the-sexes game between $[\mathrm{FI}, \mathrm{F}]$ ank $[\mathrm{L}, \mathrm{L}]$ ankl then

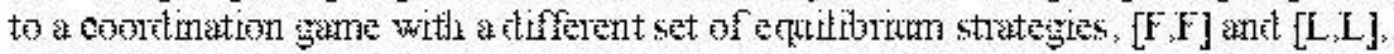

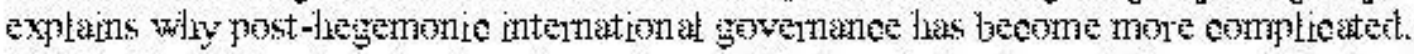
The first transition involved no dumge in equilibrim strategies, and the same foeal point equilibrum (Selkelling 1960 ) couth be maintained. The latter transition, thowever,

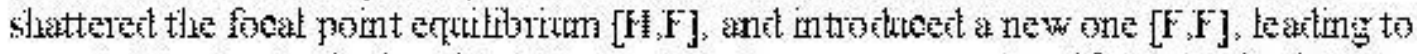

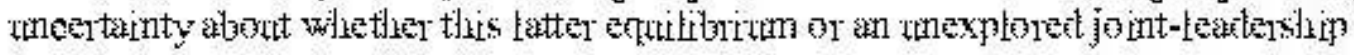
entrilitirum $[\mathrm{L}, \mathrm{L}]$ is to be clusen.

[Page 64 ]

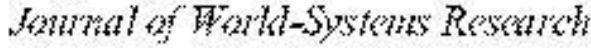

\section{Inplications of Parametric Changes Within the Model}

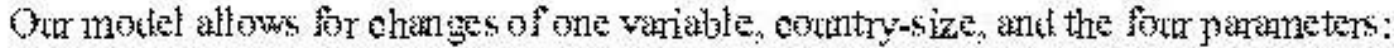

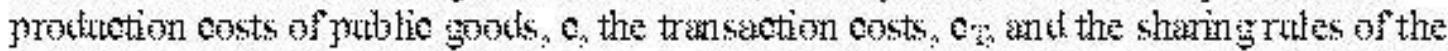

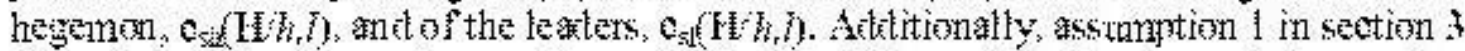

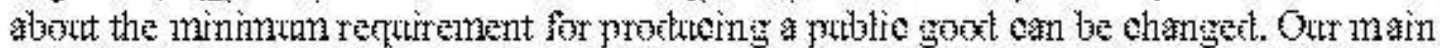

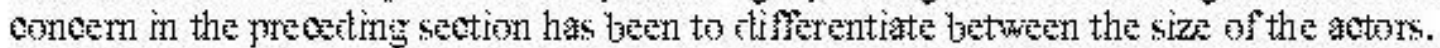

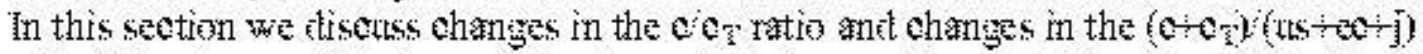
ratio. It is also posstole to vary the shape of the transetion-oosts funetion (A.1), although this etos not change the nature of our argument and will thrs not be tiseused further. Moreover, it is possible to vary the elistribution of costs between the aters and to change

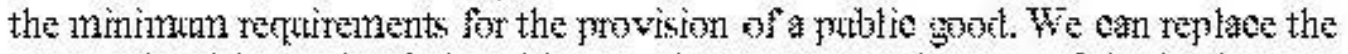
ascungtion 1 in seetion 3 that either one hegemon or at least two joint leaters are

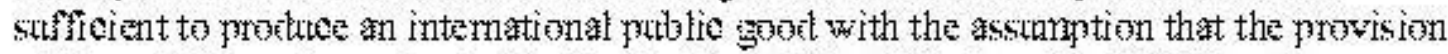

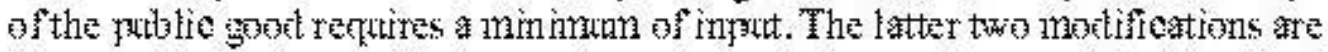

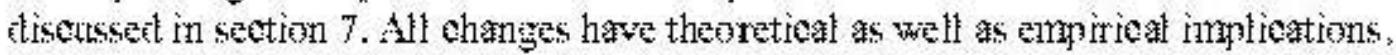
with richer ingplieations if paranetes vary eoneurrently. 
Most important for our study, the general structure of the game, which strongly advocates bilateral leadership, does not change unless the size of the Japanese economy rises well above $.25 \mathrm{and} /$ or the size of the dominant actor decreases to about .30 . This implies that joint leadership of more than two countries only pays if the actors are similar or even equal in size. Tripartite leadership is unlikely to occur even when the public good yields a high payoff and the costs, including transaction costs, of its production are low.

[Page 65]

Journal of World-Systems Research

Transaction costs originate from policy changes and international negotiations. They emerge when actors have to identify the possible effects of their action, when they are trying to identify their best option, and when actors are bargaining about an agreement (Scharpf/ Mohr 1994: 46). These aspects can but need not be quite costly. Generally, one should expect that rising transaction costs increase the probability that a public good will not be provided. In our model decreasing transaction costs lead to a greater number of possible equilibria in which the public good is provided. Most important to note, even in the period after 1970 , as shown in Table 5.1 , the $[\mathrm{F}, \mathrm{F}, \mathrm{F}]$ option is no longer an equilibrium if transaction costs are low. Instead, the US has an incentive to provide the public good unilaterally if it is unable to coerce the EC or Japan to lead jointly. Therefore, the model implicates a sharp increase in the probability that the public good will be produced in the event of the transaction costs $C_{T}$ being low. The lower the cost $c$ of producing the public good, the more probable is unilateral or joint leadership. As we discuss in more detail over the next sections, a multiplicity of possible equilibria leads to a second-order problem of which equilibria to choose. There will be disagreement between the actors, stemming from the different distribution of net gains from the different equilibria. While the US is indifferent in regard to which actor it will share the leadership role with, either the EC and Japan have a strong incentive to follow if the other actor (EC or Japan) leads. Between the EC and Japan there is a first-mover advantage in committing to follow, which involves letting the other bear the cost of leadership. Conflict occurs not only between the EC and Japan, but also between Japan and the US as well as between the EC and the US if the US tries to coerce one of the former to join in leadership. Considered from the EC's viewpoint, the preference structure is $\mathrm{P}_{\mathrm{US} / \mathrm{Jap}}=3.5>$ $\mathrm{P}_{\mathrm{US} / \mathrm{EC}}=0.2>\mathrm{P}_{\mathrm{US}}$ sole leader $=0$. However, since Japan has a dominant strategy of following for all public goods whose production and transaction $\operatorname{costs} c+c_{\mathrm{T}}$ exceed 3.0 , the EC has a weak incentive to lead. It is important to note, however, that the absence of transaction costs and low costs of the public good lead to a situation in which more than two Nash-equilibria are possible. With $\mathrm{c}=2.4$ and no transaction costs, that is $\mathrm{c}_{\mathrm{T}}=0$, our $3 \times 2 \times 2$-model gives the payoff matrix in Table 5.1.

[Page 66]

Journal of World-Systems Research 
$E C$

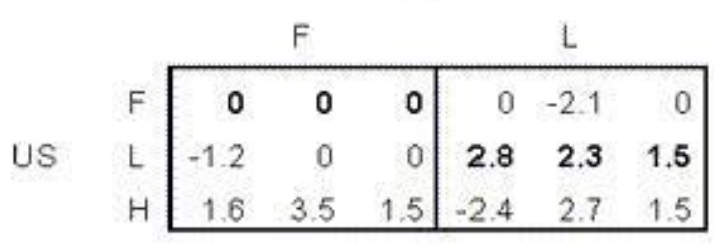

Japan follows

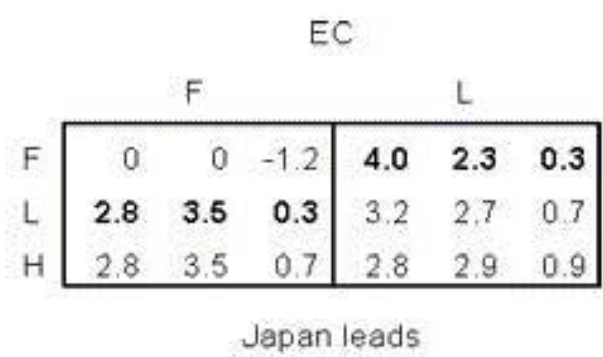

Japan leads

Table 5.1 The game in 1975 with $c=2.4$ and $c r=0$

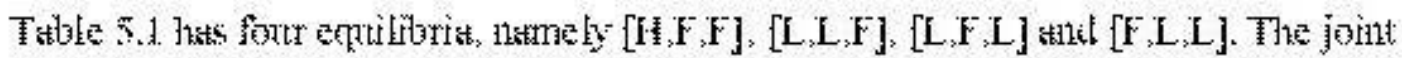

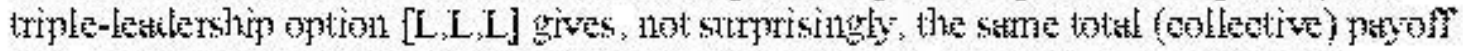

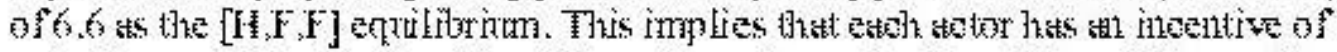

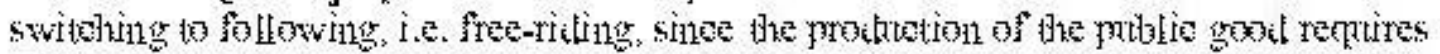

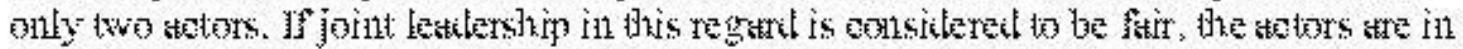

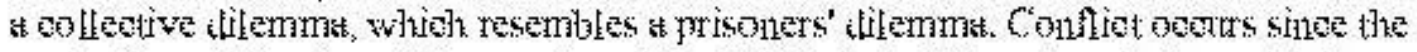

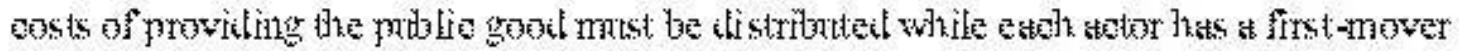

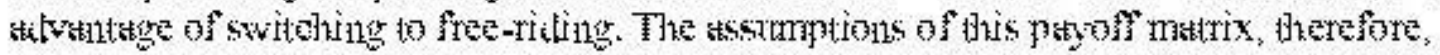

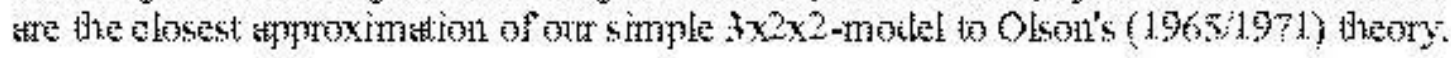

[Page 6?]

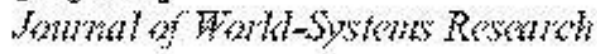

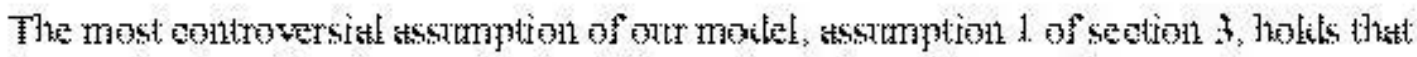

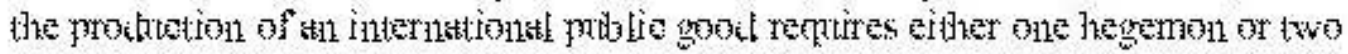

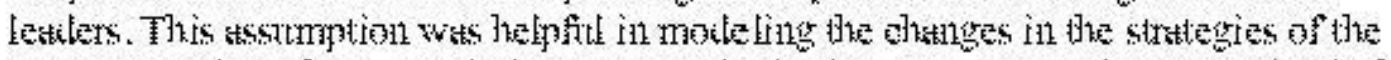

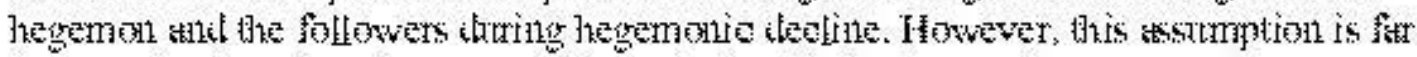

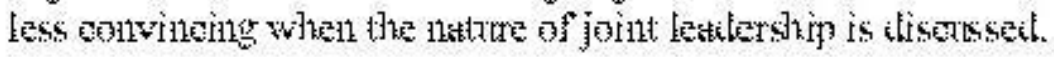

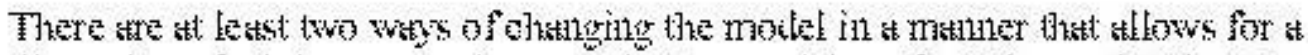

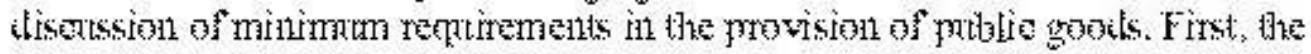

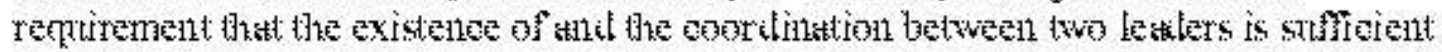

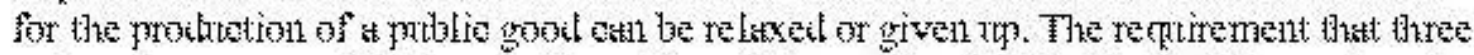

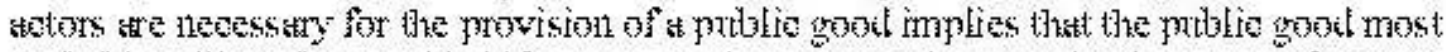

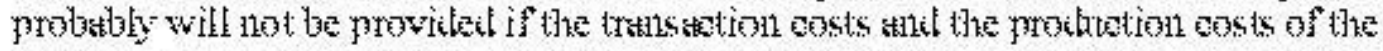

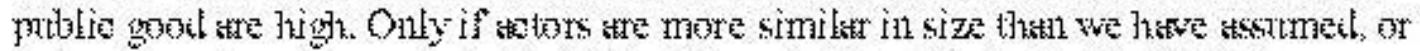

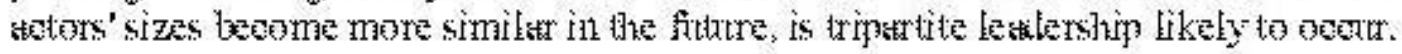

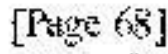

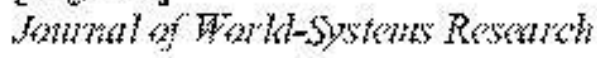

The secendil way of atlowing for a closer atymoximation to reation involves the

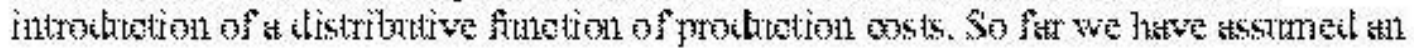


equal distribution of costs between all actors in a joint-leadership group. As Yoichi Funabashi has shown, it is - at least in some issue-areas - possible to distribute costs between actors unequally. In his analysis of exchange-rate management within the Group of 5 and the Group of 7 , he pointed out that the distribution of intervention shares was a major source of political conflict. While in the first draft proposal of joint action the distribution was $25 \%$ for the US, $25 \%$ for Japan and $50 \%$ for the EC, the compromise plan proposed a share of $30 \%$ each for the US and Japan and $40 \%$ for the EC (Funabashi 1988: 20). Incorporating these assumptions into our model while using the comparative sizes of 1985 from the Penn World Tables, we arrive at what resembles a prisoners' dilemma with $[\mathrm{F}, \mathrm{F}, \mathrm{F}]$ as the unique Nash equilibrium. However, with joint action, all actors can receive a higher payoff both collectively and individually. The distribution of costs within the European Community has involved smaller shares for Great Britain, France and the smaller countries than it has for Germany. It seems that Germany has found this distribution unfair and has thus not covered the cost in full. Hence it is hardly surprising that Germany has later been accused of free-riding by the US. The smooth cooperation of Japan, however, is not predicted by the model. The model predicts that Japan should be much more reluctant to lead than has actually happened. It is feasible, however, that the US coerced Japan to lead, since the economic imbalances between both countries made Japan vulnerable to political pressure.

[Page 69]

Journal of World-Systems Research

Concluding this section, we now summarize the implications of our model. The following hypotheses emerge from the preceding analysis:

1. Increasing the cost $\mathrm{c}$ of producing the public good reduces the possibility for one single actor to act as a hegemon because this becomes too costly. Increasing the cost of producing the public good, in response to a world economic crisis for example, requires joint leadership even if the capabilities of the hegemon are sufficient to stabilize international regimes in normal situations.

2. Decreasing the transaction costs $c_{\mathrm{T}}$ of producing the public good increases the likelihood of the emergence of joint leadership. In our model it increases the number of Nash equilibria in which multiple leaders jointly provide the public good.

3. The possibility of distributing production costs of a public good among multiple actors increases the likelihood of joint leadership even though the situation still resembles a coordination game and distributive conflict might prevent actors from reaching a jointleadership equilibrium.

4. The number of actors participating in joint leadership depends predominantly on the minimum requirement for their production. In addition, it is influenced by the shape of the transaction-cost function, $\mathrm{c}_{\mathrm{T}}$ in equation (3.1). If additional actors do not significantly 
increase the transaction costs of decision-making, the probability of tripartite leadership increases.

Joint-leadership systems require an agreement between the members of a small or a 'kgroup' on every political action which needs policy coordination. Contrary to what is the case for a hegemonic system, different interests have to be taken into account. This not only increases transaction costs, but also makes agreement problematic even if actors agree that a coordinated solution is in the interest of all actors. Considerations of this kind have led Robert Keohane to distinguish between harmony and cooperation (Keohane 1984: 51). While harmony refers to a situation in which the pursuit of self-interest by one actor contributes to the interest of all, cooperation requires that conflicting viewpoints and actions are brought into conformity:

[Page 70]

Journal of World-Systems Research

Cooperation therefore does not imply an absence of conflict. On the contrary, it is typically mixed with conflict and reflects partially successful efforts to overcome conflict, real or potential. Cooperation takes place only in situations in which actors perceive that their policies are actually or potentially in conflict, not where there is harmony. (Keohane 1984: 53-54)

In other words, Keohane argues that cooperation is needed to overcome conflict stemming from uncoordinated policies that lead to suboptimal outcomes for all actors. The situation Keohane has in mind and analyzes resembles a typical prisoners' dilemma. Joint action can help the actors to achieve a better outcome if an institution is implemented. This allows for an easy observation of the noncooperative beh avior of actors and helps to enforce rules.

In a prisoners' dilemma an agreement on mutual cooperation should be easy to negotiate, but the enforcement of the norms is difficult. This is the reason why a strong institutional setting, a dominant group of countries which seek to enforce the agreement, may help to create and stabilize international regimes (Martin 1993: 99). However, from this perspective it is quite unclear why a hegemon should unilaterally create and maintain international public goods. With the assistance of other main actors it would be easier to ensure rule compliance. A similar assumption holds for joint leadership exercised by a limited number of countries. We discuss this topic, based on the notion of transaction costs, in the following section. Returning to the assumption of equation (3.2) that coercive hegemony is possible, we analyze the structural requirements, which lead to such a constellation in one issue-area.

[Page 71]

Joumal of World-Systems Research 


\section{$\underline{6}$ Coercive and Benevolent Hegemony and Leadership}

The assumption that multiple actors join in the production of public goods partly contradicts the empirical findings of hegemonic eras as well as contemporary world politics. The central decision-making body for international economic leadership is the world economic summit. This institution embodies the United States, Canada, Japan, Germany, France, Great Britain and Italy. Our model accounts for disagreement, since it assumes increasing transaction costs when the number of actors participating in the decision-making process increases. Furthermore, our model also encapsulates a second and more political notion of disagreement: in all cases in which more than one equilibrium leads to the provision of international public goods, we should expect political conflict over the proper way to produce it.

The analysis of our model has led to the conclusion that the emergence of joint leadership yields multiple equilibria, implying that contemporary world politics does not resemble a prisoners' dilemma but rather a coordination game emerging from an earlier battle-of-thesexes game. In this case as well as in classical hegemonic constellations, actors can use power resources to cause other countries to participate in the production of international public goods.

During the declining phase of US hegemony, the main source of conflict has been whether other countries, most notably European countries or Japan, should share the leadership role with the US. It had been possible for the US to force European countries and Japan to share the burdens of international leadership. In current world politics, the main source of disagreement is rather which two leaders should contribute to the provision of international public goods, or whether trilateral leadership is appropriate. The leaders can be selected 'randomly' or based on their interest in special issue-areas. Actors can also use power to change 'natural' leadership constellations. They can urge followers to participate in the production of an international public good.

[Page 72]

Journal of World-Systems Research

Pertaining to these issues, there is currently much ongoing debate regarding whether the leader acts benevolently or coercively. Beth and Robert Yarbrough (1992: 50), for example, state that the main source of disagreement within hegemonic stability theory stems from the extent of benevolence or exploitation (coercion) by the hegemon. The model in section 3 allows us to make a more succinct specification of whether the hegemon will act benevolently or coercively [10]. If we assume that coercion is more costly than benevolence, the cost of coercion can then be considered as part of the hegemon's transaction costs $c_{\text {Thco }}=\mathrm{c}_{\mathrm{T}}$ given in equation (3.1). We thus rewrite (3.1) so that 
$c_{\text {Thco }}(h+l)=\frac{12 k}{5}(h+l-1)$ for $h+l \geq 1$

Where the parameter $k$ increases as the cost of coercion increases. We assme that the nature of hegemonio coercion of other actors, whether it is throuth providing positive incentives or negative sanctions, is such that the other adtors get a tigher payof from compliance then from non-eompliane. The hegemon will ad benevolently if

$P\left(H_{B} / h=1, l=0\right)>P\left(H_{C} / h=1, l\right)$

Inserting (3.4) into (6.2) gives

$c_{s h}(H / 1, l)\left(c+c_{\text {Tho }}(1+l)\right)>c$

[Page 73]

Janual tof Work-Systene Rewath

Inserting $(6.1)$ into $(6.3)$ for $\gamma_{2}=1$ and resolving with regard to $\mathrm{k}$ gives that the hegemon will ad benevolently if

$k>\frac{5 c}{12 l}\left(\frac{1}{c_{s h}(H / 1, l)}-1\right)$

If (6.4) is not satis fied, the hegemon will ooeree two other ators ratther than one to leat

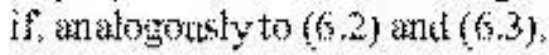

$-c_{s h}(H / 1,2)\left(c+c_{\text {Tho }}(3)\right)>-c_{s h}(H / 1,1)\left(c+c_{\text {Thoo }}(2)\right)$

Inserting (6.1) into (6.5) for $y_{k}=1$ and resolving with regard to $\mathrm{k}$ gives that the hegemon will coeree two otther actors rather than one to leat if

$k<\frac{5 c}{12}\left(\frac{c_{s h}(H / 1,1)-c_{s h}(H / 1,2)}{2 c_{s h}(H / 1,2)-c_{s h}(H / 1,1)}\right)$

Let ths asstme $\sigma=4.2=215$. Inserting the sharing rate $(3.2)$ into $(6.4)$ and $(6.6)$ then implies that the hegemon will aot benevolently if $k \sim 7 / 8$ and will ooeroe the two other actors to leat if $\mathrm{k}\left(7 / 8\right.$. With a sharmg rute $\mathrm{c}_{\mathrm{s} 2}(\pi / 1,1)=2 / 3$ (as be fore) and os $(\pi / 1,2)=3 / 5$, the hegemon will as benevolently if $k \sim 7 / 8$, will ooere one other ador to leat if

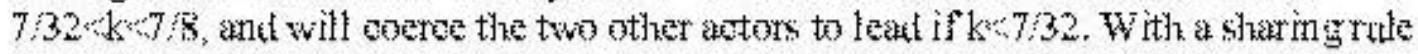
$\mathrm{c}_{\mathrm{s} \alpha}(\mathrm{T} / 1,1)=3 / 5$ and $\mathrm{c}_{\mathrm{s} \alpha}(\mathrm{T} / 1,2)=1 / 2$ (as before), the hegemon will act benevolently if 
$\mathrm{k}>7 / 6$, will coerce one other actor to lead if $7 / 16<\mathrm{k}<7 / 6$, and will coerce the two other actors to lead if $k<7 / 16$. A hegemon therefore acts unilaterally if it considers the costs of coercion higher than the possible contribution of followers. The probability of coercion increases the more costly an international public good is and the lower the transaction costs are.

[Page 74]

Journal of World-Systems Research

The question of benevolence versus coercion is also relevant in a situation of joint leadership where hegemony is absent. Benevolent leadership occurs if a couple or a group of actors can produce the public good without other possible leaders since the institutional costs of rule enforcement exceed the enforceable contribution of followers. Coercive leadership occurs if the cost of punishing defectors is outweighed by the contribution defectors make when they switch to cooperation. A case of coercive leadership is the multilateral exchange-rate management within the institutional setting of the world economic summit between the Plaza and the Louvre agreement (Funabashi 1988). [11]

\section{An Exhaustive Characterization of the Equilibrium Strategies}

This section provides an exhaustive characterization of all the possible equilibria for the model in section 3: for four different costs $c$ of producing the public good, that is $c=4.2$, $c=4.8, c=6$ and $c=3.6$, given transaction costs $c_{T}$ according to equation (3.1), that is given $\mathrm{c}_{\mathrm{T}}(2)=2.4$ and $\mathrm{c}_{\mathrm{T}}(3)=4.8$. The change we make in the assumption is to allow all three actors, the US, the EC and Japan, to choose between the three strategies of being a hegemon, a leader or a follower. Both changes bring symmetry into the analysis and provide for a more timeless evaluation which is valid for any three actors, any of which may emerge as a future hegemon. We also assume for simplicity that us $+e c+j=90=$ constant. A cost $c=4.2$ of producing the public good gives the equilibrium characterization in Fig. 7.1. 


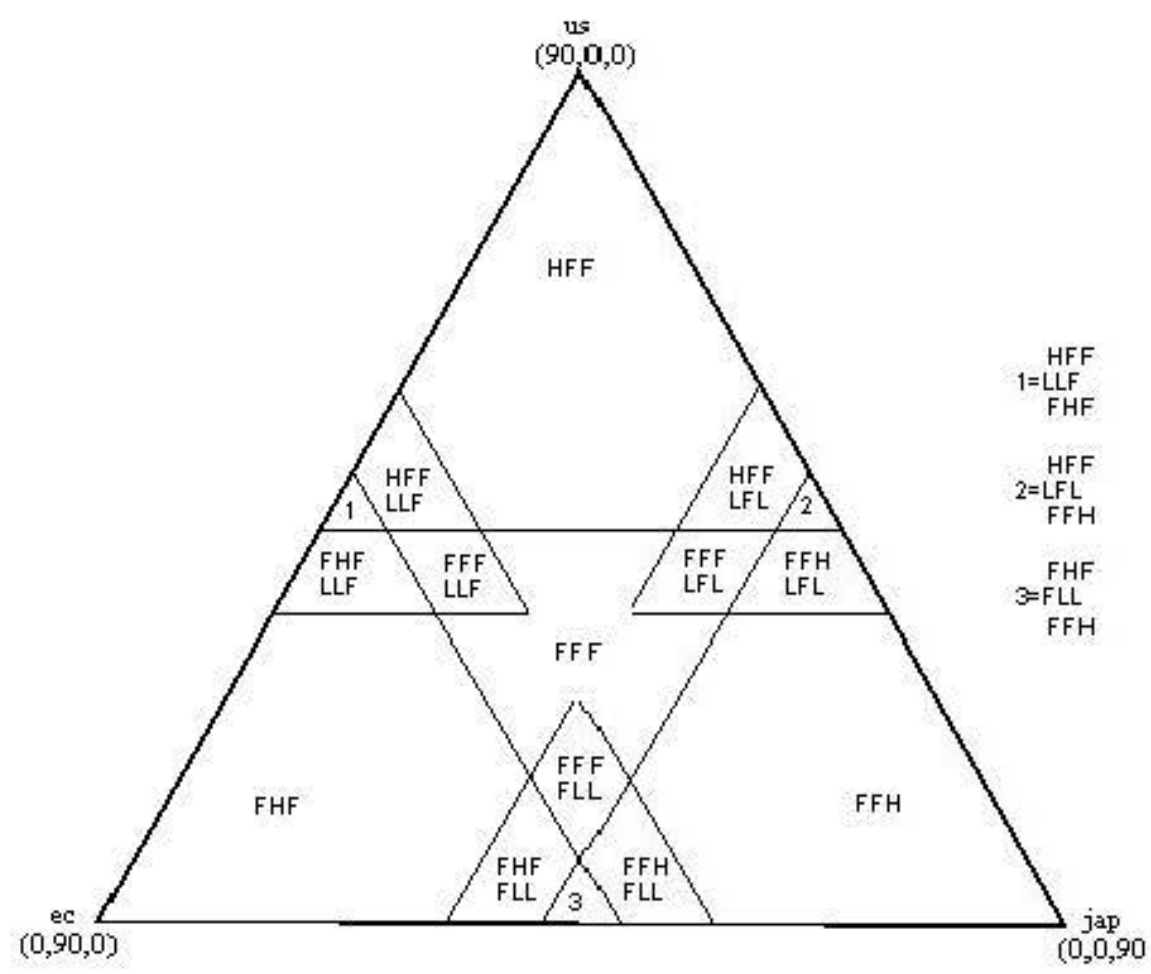

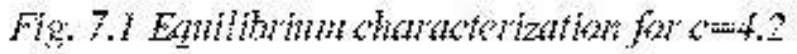

[Page 75]

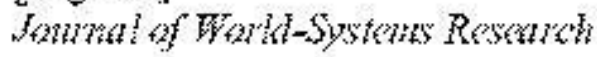

Fig. 7.1. shows that one pretominant adtor, say the LS, leats to the rningte le gemonie

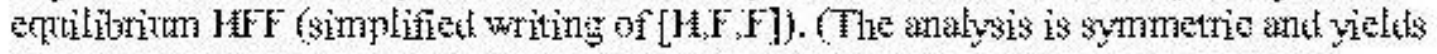

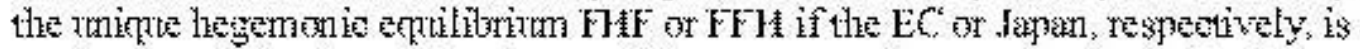

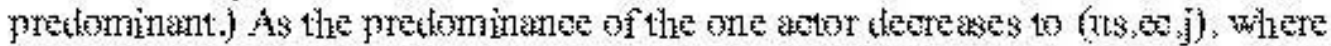

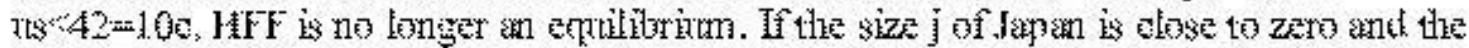

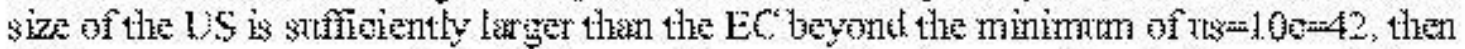
LLF meryes as a second entilibrixm, as illistrated by the trapezim in the ropger left part. The reason is that the relative sizzs of the EC ant the LS converge, restling in the

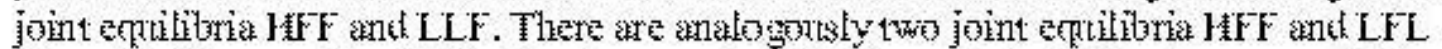

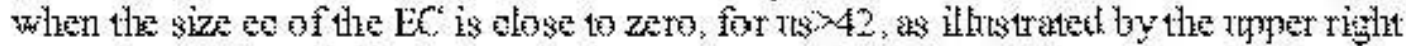
tranezim. If the sizz $\mathrm{j}$ of Japan is olose to zero and the size of the LS is artfieienty

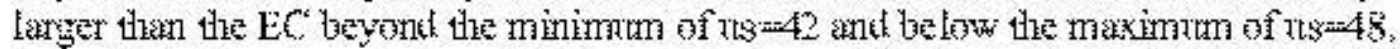

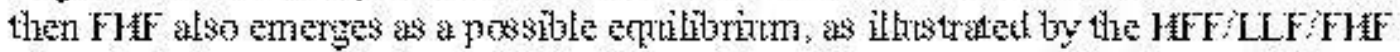

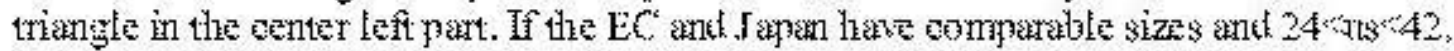

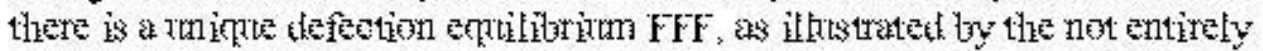

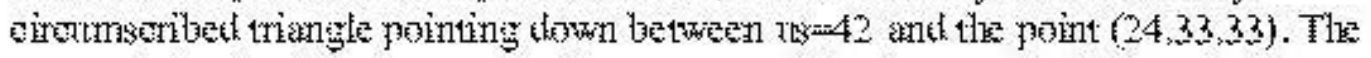

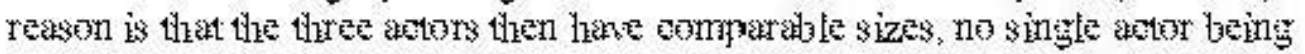

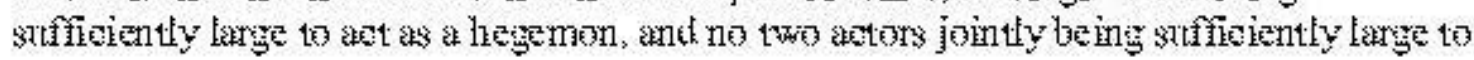




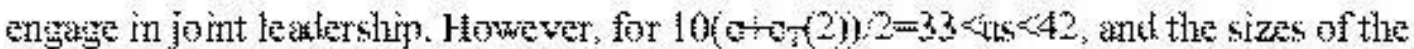

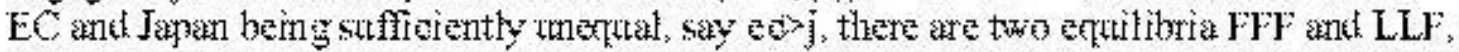
as illustrated by the parallelogram slightly to the left from the enter $(30,30,30)$. The reasen is that the US and the EC are then bath steffeiently large to frovite joint

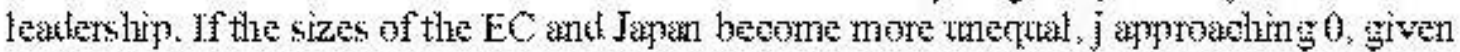

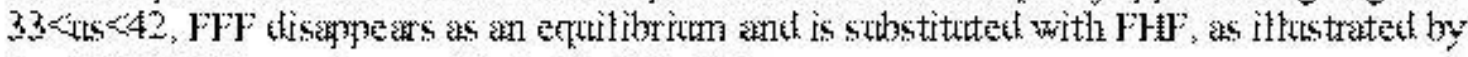
the FHF LLF trapezirm on the left in Fig. 7.1.

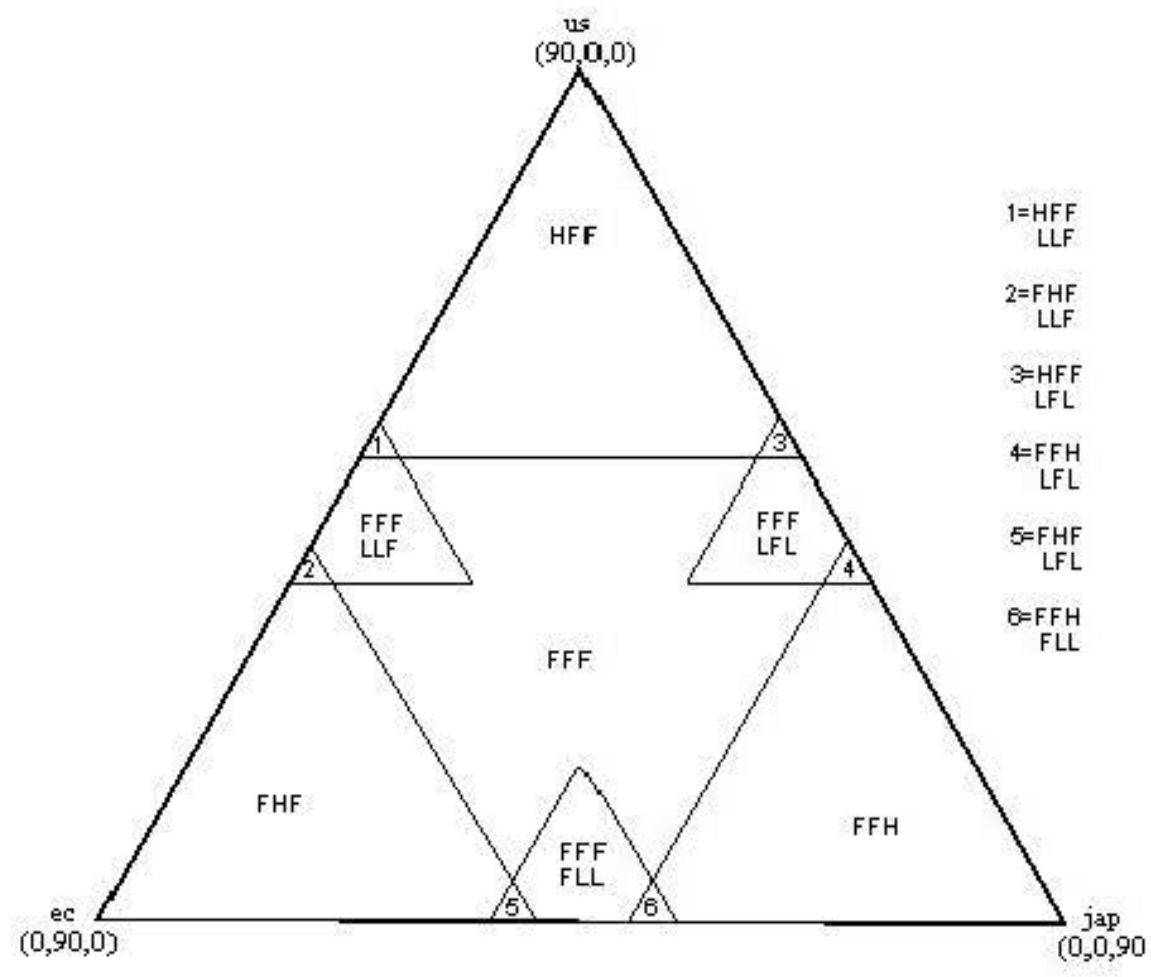

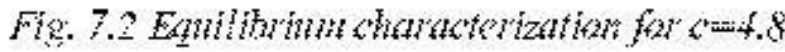

[Page 76]

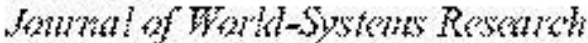

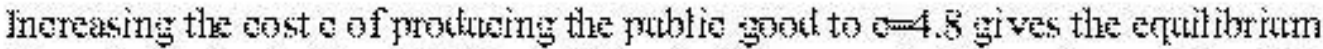
dharaderization in Fig. 7.2. Fig. 7.2 illustrates a more striet requirement for attaining a

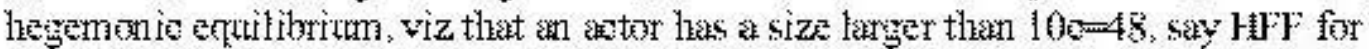

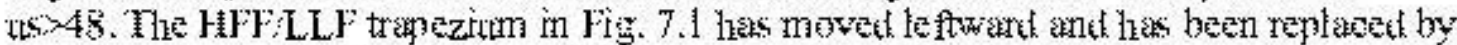
the tiny triange far left in Fig. 7.2 for the size of the LS bemg slightly larger then the 48 and the size of Japan be ing sufficiently olose to jum. The 'down wath direded triangle,

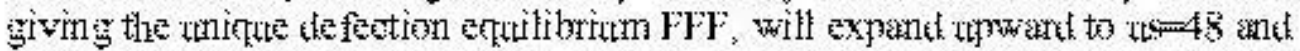
thownwark to the point $(18,36,36)$. Futher, the FFF LLF parallelogram in Fig. 7.1 has moved leftwatk and been replated by the frve-edged areat to the left in Fig. 7.2. Finally,

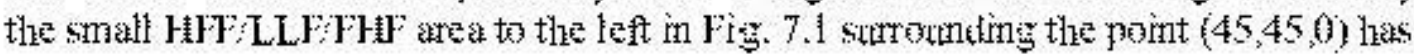


thisameared sinee hegemony is no longer possible when the sizz of an ador is less than 48.

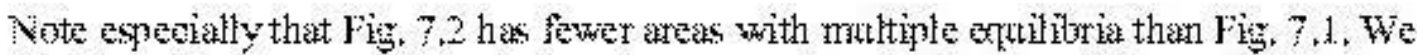

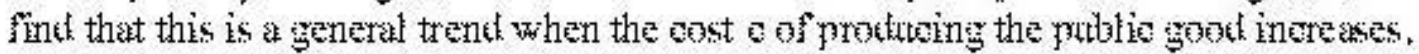
The reasen is that the more striet requirement for hegemeny yielis a smaller lofF area (if an ador is stficiently large, which is less likely), a larger FFF area (if the ador sizes onverge, which is more likely), and very few areas where joint leakership atone or ombined with a hegemany or a follower strategy is jassible (if two adors are omparaly large and the thirk ador is small, whidh also is less likely).

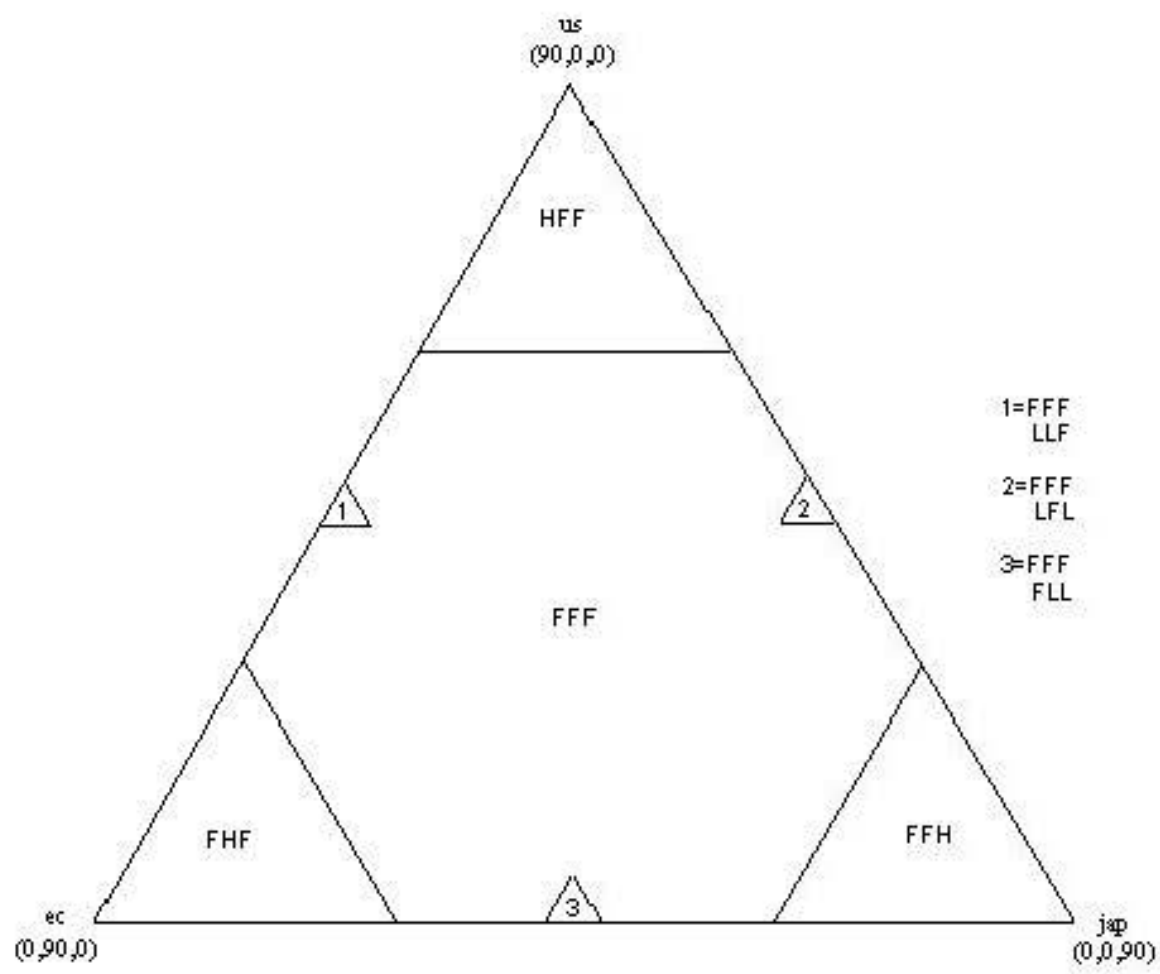

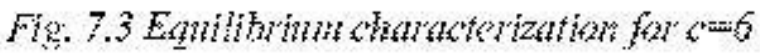

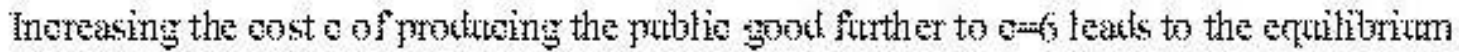

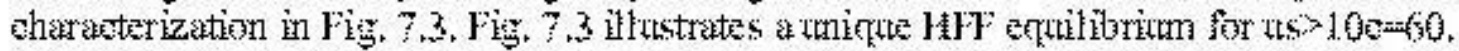

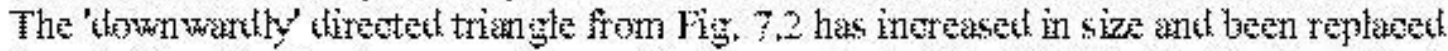
by what is vituklly a hexagon surrownding the enter in Fig. 7.3. Finally, the five-edged areat the left in Fig. 7.2 has beome smaller and been replased by the tiny PFF:LLF trisugle to the left in Fig, 7,1 surrownding the point $(45,45,0)$.

[Page $7 /]$

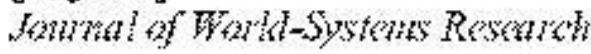




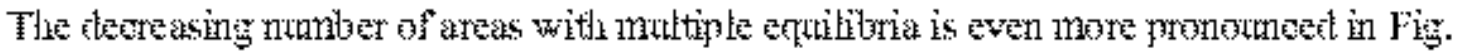

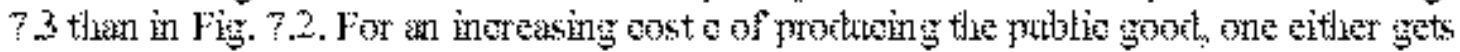

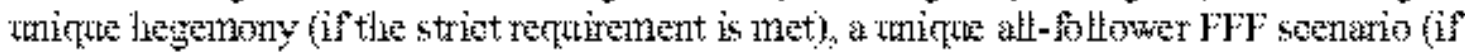

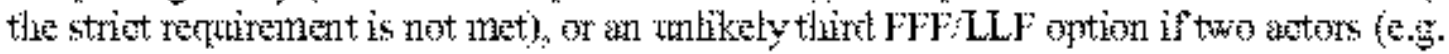

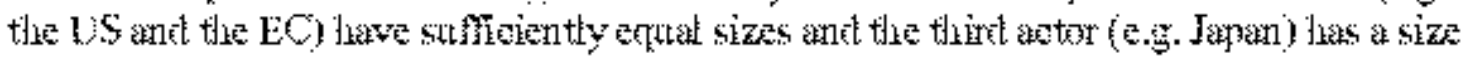
sufficiently dose to zero.

As the oost of of

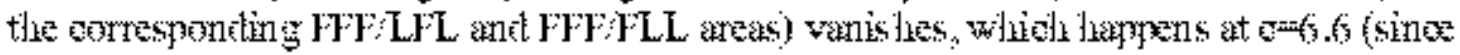

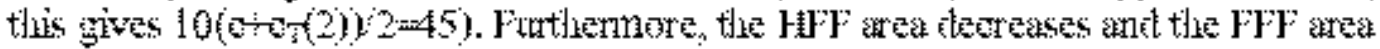

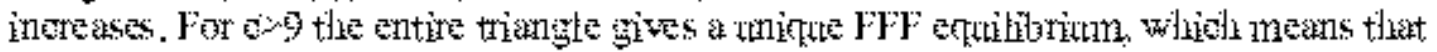

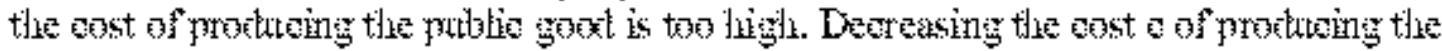

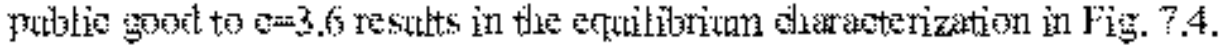

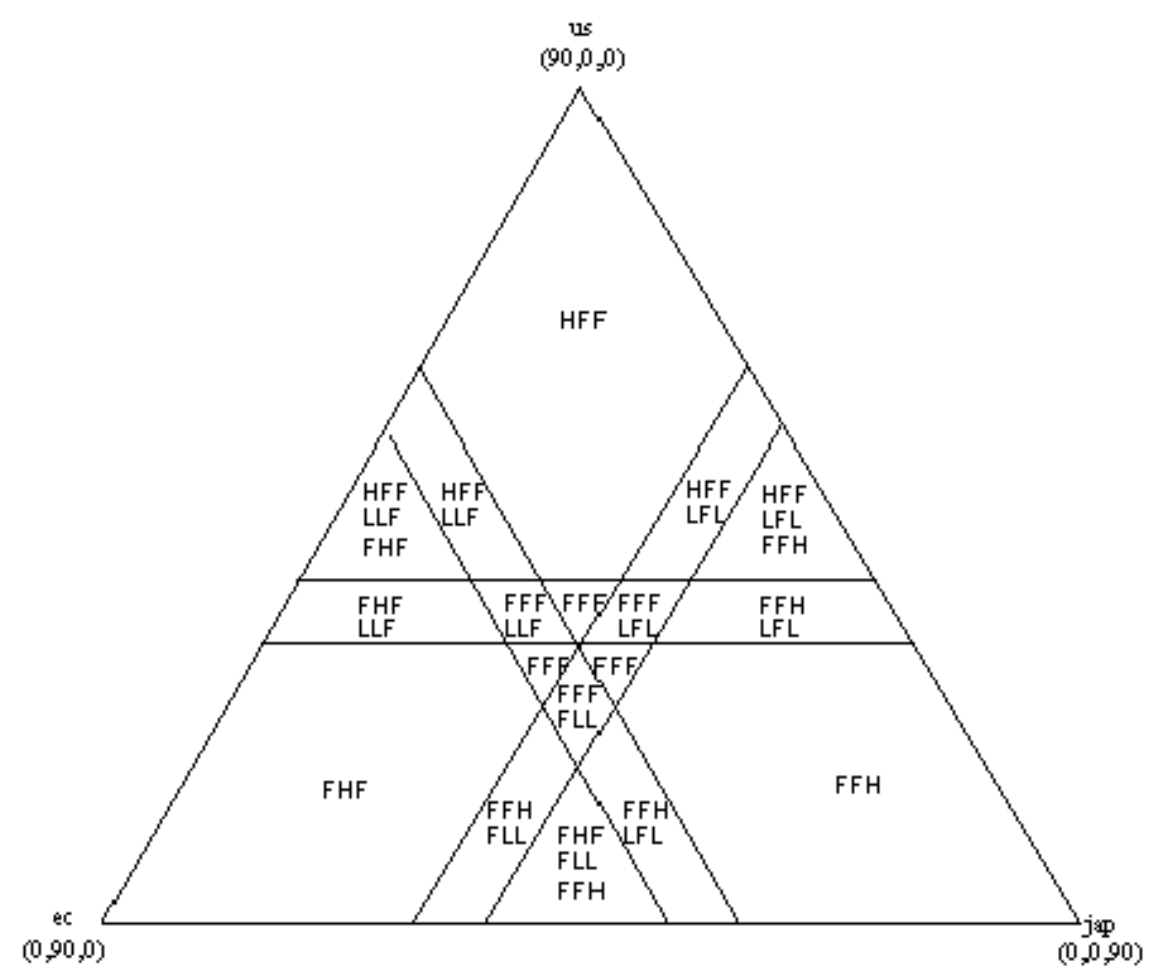

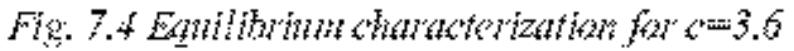

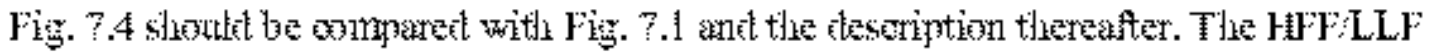

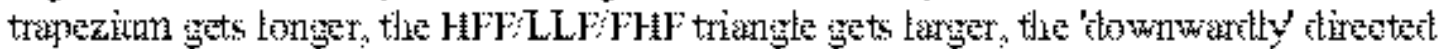

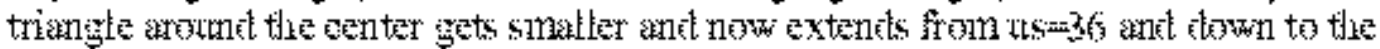

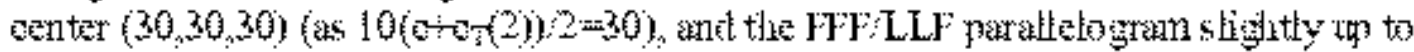
the left moves towatal the oenter $(30,30,30)$ and inginges on it.

[Page 78]

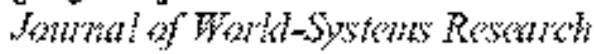


As $c$ decreases further, given $3<c<3.6$, the two trapezia HFF/LLF and FHF/LLF (and their analogs) become narrower and gradually turn into parallelograms, the FFF/LLF parallelogram and the FFF triangle (and their analogs) gradually vanish, and the HFF/LLF/FHF triangle (and its analogs) becomes larger and gradually turns into a trapezium. For $c=3$ hegemony is possible for all combinations of $0>-u s, e c, j<=90$, where us $+\mathrm{ec}+\mathrm{j}=90$. More specifically, for $\mathrm{c}=3$ the center 'upwardly' directed triangle stretching from us $=10\left(\mathrm{c}+\mathrm{c}_{\mathrm{T}}(2)\right) / 2=27$ to the point $(36,27,27)$ consists of three sub-triangles and three sub-parallelograms. All these six areas allow for the three equilibria LLF, LFL, and FLL. Each sub-parallelogram also allows for one hegemonic option, the upper one e.g. for HFF. Each sub-triangle also allows for two hegemonic options, the left one e.g. for HFF and FHF.

As c decreases further to $c=2.4$, in which case $10 \mathrm{c}=10\left(\mathrm{c}+\mathrm{c}_{\mathrm{T}}(2)\right) / 2=24$, the center triangle gradually increases in size to stretch from us $=24$ to the point $(42,24,24)$ and gradually changes in content of equilibria to allow for all the six equilibria HFF, FHF, FFH, LLF, LFL, FLL. Simultaneously, the two parallelograms HFF/LLF and FHF/LLF (and their analogs) gradually vanish, being replaced by the HFF/LLF/FHF trapezium (and its analogs), which is increasing in size. The area for each unique hegemonic equilibrium in each corner, e.g. HFF close to the upper point $(90,0,0)$, also gradually decreases in size.

Decreasing the cost $\mathrm{c}$ of producing the public good to $\mathrm{c}=1.8$ results in the equilibrium characterization in Fig. 7.5.

Fig. 7.5 is noteworthy since unilateral production of public goods, for $c>2.4$, is less costly for a single actor than half the cost of bilateral joint production of public goods. This constellation appears if $\mathrm{c}$ is smaller than $\mathrm{c}_{\mathrm{T}}$. Nevertheless, joint leadership remains a viable option when two actors are nearly equal in size.

[Page 79]

Journal of World-Systems Research

Decreasing $\mathrm{c}$ further to $\mathrm{c}=0$ moves the us $=10 \mathrm{c}=18$ line in Fig. 7.5 gradually downwards to the us $=10 \mathrm{c}=0$ line, while the us $=10\left(\mathrm{c}+\mathrm{c}_{\mathrm{T}}(2)\right) / 2=21$ line in Fig. 7.5 is moved gradually downwards to the us $=10\left(\mathrm{c}+\mathrm{c}_{\mathrm{T}}(2)\right) / 2=12$ line. As the reader can see, each of the three corner parallelograms allows for all the three hegemonic options HFF, FHF, and FFH. Further, the center triangle gets larger, spanned by the points $(66,12,12),(12,66,12)$, and $(12,12,66)$.

Analyzing the triangles in political terms leads to the following conclusions. The way an international public good will be produced greatly depends on the costs which are necessary to produce it and on the relative size of the actors. Observe that in the discussion from $c=3.6$ in Fig. 7.4 , to $c=3$, then to $c=2.4$, then to $c=1.8$ in Fig. 7.5 , and 
fintaly to $=0$ in the previous paragraph, there is a gratual inerease in the number of

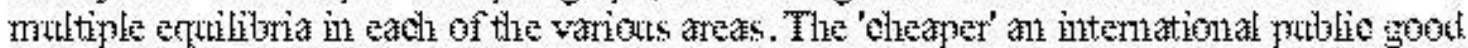
is, the easier it is to produce politioal solutions, but the highter is the politieal confliet resulting from the free-riker froblem. This is the reverse effeet, which is consistent with the trenk kescribed above that the number of areas with multiple entulibria deereases as

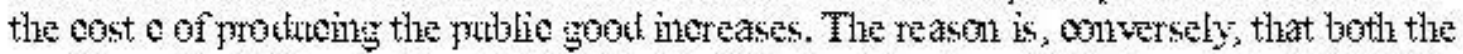
rentrirements for hegemony and joint leatarilijp are now less striet, as well as that $\mathrm{FT}$ is still an ortion if $\mathrm{e}>3$ anth the sizes of the there aetors are suffieiently ental. In other

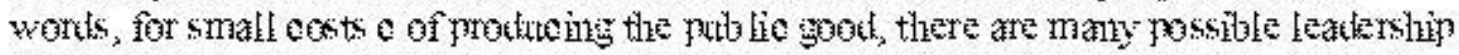
constellations, viz legemony (alwas possibe given o 3 ), or joint leatersiliz, or an allfollower situation (if 10 single aetor is comparably large ant $0>3$ ). Even if there was a

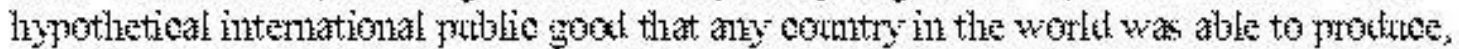
it would still be possible for all countries to stay asike. Extremely expensive intemational putble goods can only be wrovided by a hegemon. The yroblem stemming from joint leakershin in regark to costly provision of the yutblio gook is that transwion costs exeed the gains from joint aetion.

\section{[Page sio]}

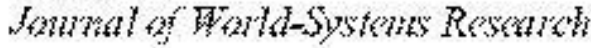

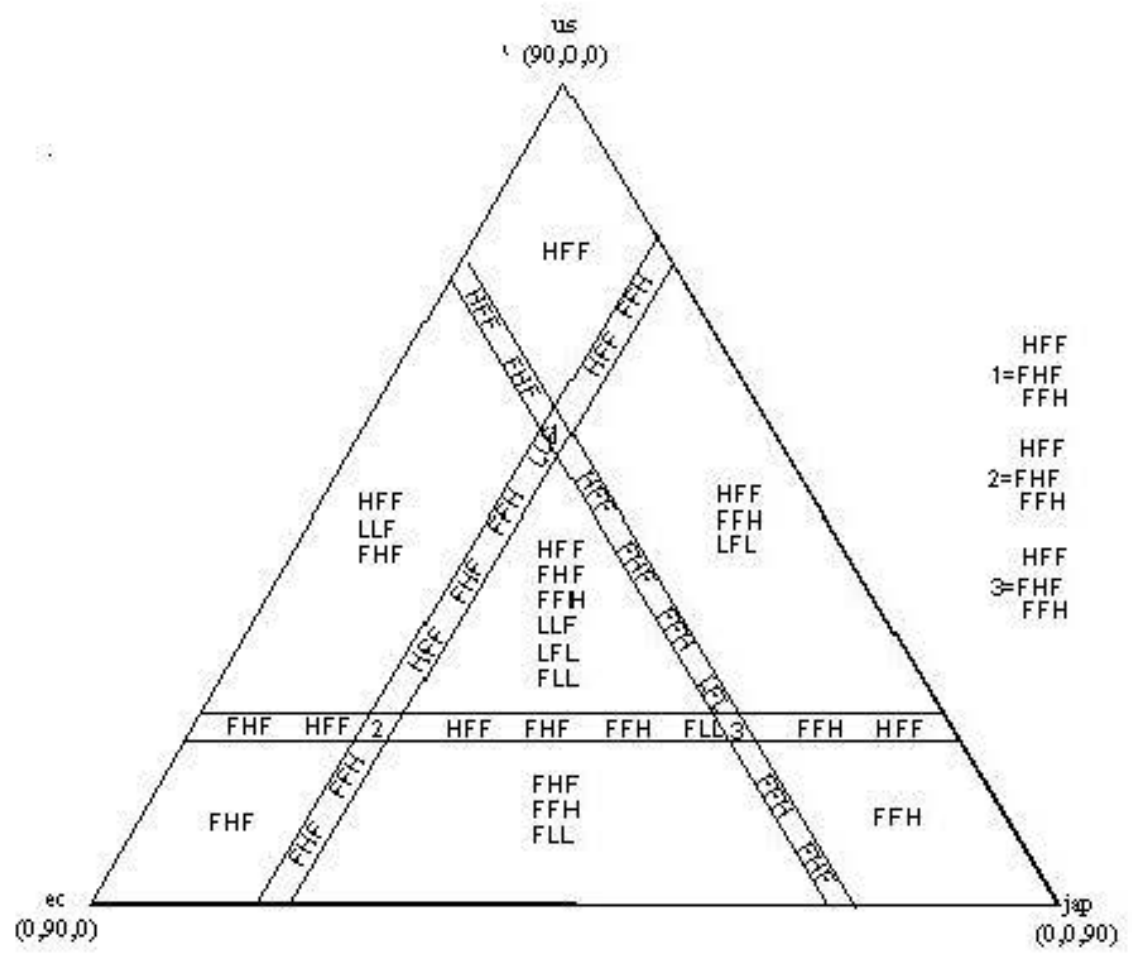

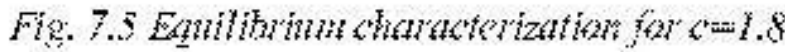




\section{$\underline{8}$ Future Leadership Constellations and the Quest for International Order}

Any stylized model has its limitations. This model analyzes the problem of size in collective action. Its limitations mainly stem from the neglect of variations in the cost of providing international public goods. In the case of global economic crises, for instance, the transaction costs needed to reach an agreement may decrease considerably. Having learned the lessons from the disastrous economic consequences of the Great Depression in the 1930s, countries today may, when confronted with an economic threat of collapsing growth rates, increasing inflation and unemployment, more easily opt for joint leadership. On the other hand, the continuing integration of economic affairs leads to an increase in the price of policy changes. Our model allows for parametric changes of the cost $c$ of producing public goods and transaction $\operatorname{costs} c_{T}$, but it does not treat these as variables; the only variable in our model is size.

The strength of the model presented in this article is that it permits predictions of future leadership constellations in international political relations, given estimates of the sizes of the actors' economies, that is any combination (us,ec,j). It is also possible to assume other actors than us, ec, and $\mathrm{j}$, and it is of course possible to increase the complexity of the model to four or more than four actors, although this will complicate the analysis.

[Page 81]

Journal of World-Systems Research

Predictions are necessarily speculative though not without prece dent (Kennedy 1987; Gilpin 1987; Thurow 1992). In this concluding section we discuss the relationship between actor size and the costs of providing an international public good. We have assumed (us,ec, $\mathrm{j})=(50,35,5)$ in 1960 , (us, ec, $\mathrm{j})=(40,35,15)$ in 1975 , and we may assume (us,ec, $j)=(38,35,18)$ in 1995 . The relative sizes in 1975 and 1995 are sufficiently similar so as to give no changes in the Nash equilibria. With the possible further size convergence of the three actors we may assume (us, ec, $\mathrm{j})=(35,30,25)$, which would lead to a significant increase in the degree of conflict about leadership. Future development may lead to the emergence of a 'Pacific bloc', pac, agreed upon either by the ASEAN and Japan, by the APEC, or by an other institutional form. Let us assume (us,ec,pac) $=(25,25,25)$, which leads to the game in Table 8.1 .

The game in Table 8.1 resembles a three-person prisoners' dilemma. Everyone would benefit and receive a positive payoff 0.1 from LLL. However, each actor has an incentive to deviate unilaterally to $\mathrm{F}$ to receive the free-rider payoff 2.5. If everyone deviates to $\mathrm{F}$, however, the unique mutual-defection equilibrium FFF ensues. 


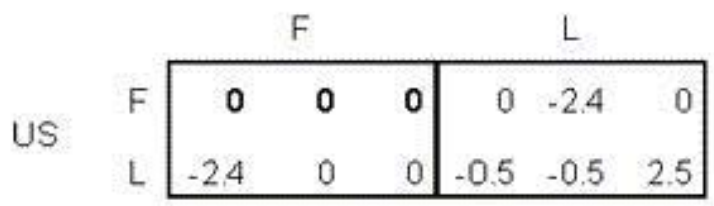

'Pacific bloc' follows

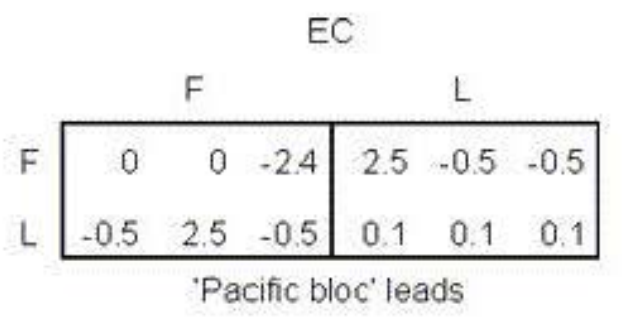

'Pacific bloc' leads

Table 8.1 Prediction of a future game with $c=4.8$

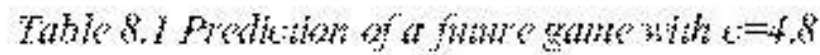

[Page $\xi_{2}$ ]

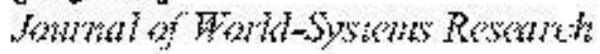

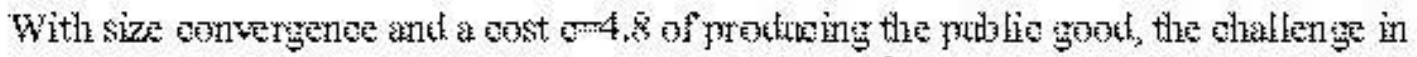
intemational relations is thus to overoome the logie of the yrisoners' dilemma, This ou

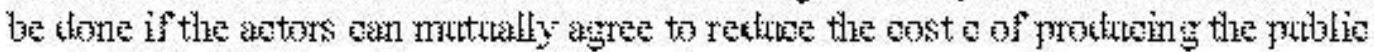

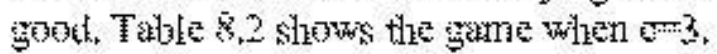

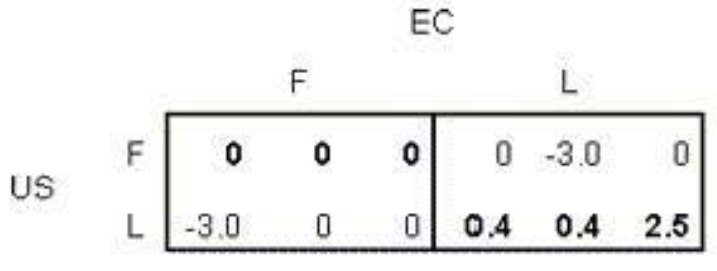

'Pacific bloc' follows

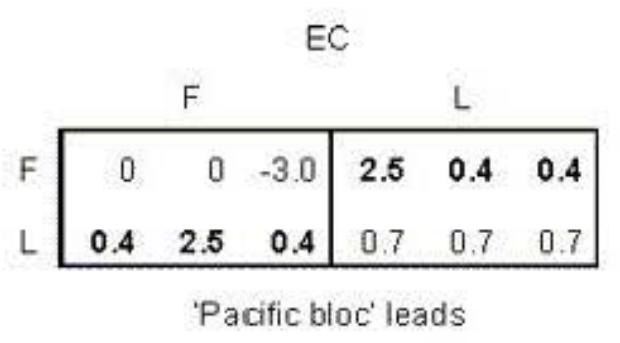

'Pacific bloc' leads

Table 8.2 Prediction of a future game with $c=3$

[Page 3 ]

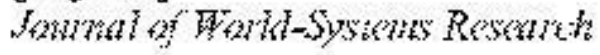

Tale 8,2 illustrates forter equilibria, LLF, LFL, FLL and FF, the former thee providing

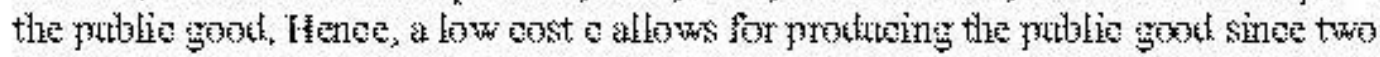

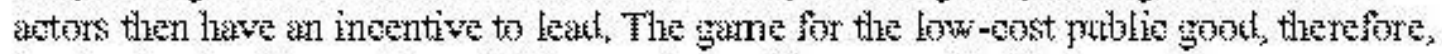

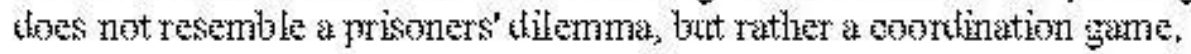

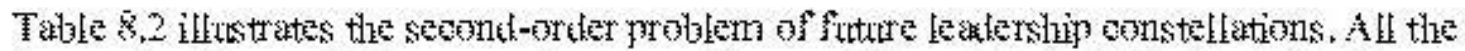
three actors have a fist-mover ak vantage of committing not to leall, illustratak by the first-mover reedving 2,5 rather then 0.4 , Henee, although the aetors may possibly be

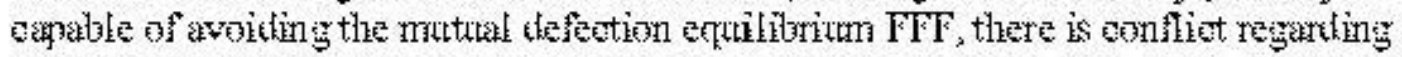

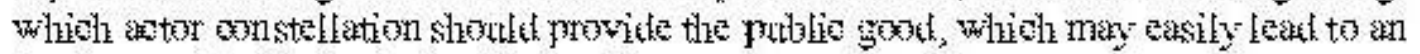
'tenkerstrgyly' of joint-leatersilis antivity. 
[Page 84]

Joumal of World-Systems Research

Although the model used in this article has shown a multiplicity of equilibria allowing for hegemonic or joint leadership, the all-follower FFF equilibrium is also a prevalent option for $\mathrm{c}>3$. Comparable to a hegemonic era where international public goods are produced with a high degree of certainty, our model predicts an increasing likelihood of international public goods not being produced if the sizes of the various actors converge. Thus, the most salient problem of contemporary and future world politics seems not to be hegemonic decline but rather the emergence and existence of multiple joint-leadership equilibria. If multiple constellations of joint leaders are able to produce international public goods, the increasing number of available strategies for each actor easily leads to situations where international public goods turn out not to be producible. That is, the probability increases that the actors find themselves in a deadlock. The possibility of agreeing upon tripartite leadership does not necessarily resolve the deadlock, both because that leads to rising transaction costs and because one actor will have an incentive to free-ride in the sense of not contributing to the production of the public goods.

It is typically the case that expensive public goods are much more likely to be provided by a hegemon than by a group of leaders. This is illustrated, for example, by Fig. 7.3, which suggests that international public goods will be provided with probability one if the size of an actor is larger than 60 (e.g. the HFF area), whereas both the all-follower FFF and the joint leadership LLF options are realizable equilibria if the US and the EC are equally large and Japan is very small in size, say (us,ec,j) $=(45,45,0)$.

[Page 85]

Journal of World-Systems Research

Furthermore, given hegemonic decline and the emergence of joint leadership, the probability increases that the largest actor may be too small to provide costly international public goods unilaterally, while the followers are too small to join in the production. This is illustrated by the center portion of Fig. 7.4. This is a plausible constellation if the second- and third-ranked actors are almost equal in size. The increasing difficulty in producing expensive public goods may lead to a situation where the actors become less likely to agree upon the establishment of international regimes which are broad in scope. One should expect, therefore, that the international regimes agreed upon by countries in the foreseeable future are more limited or sectorial in scope.

Most important, however, the article shows that 'after hegemony' international regimes can be established, and international stability and openness can be provided. A jointleadership system does not lead to anarchy and chaos, but it does require more cooperation among countries. However, a joint-leadership system leads to a different 
intenational orter than the legemenio system we have beel aceustomed to over the last halaf eentitury.

\section{Appendix: The Relative Size of OECD Actors}

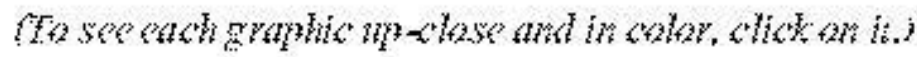

1950

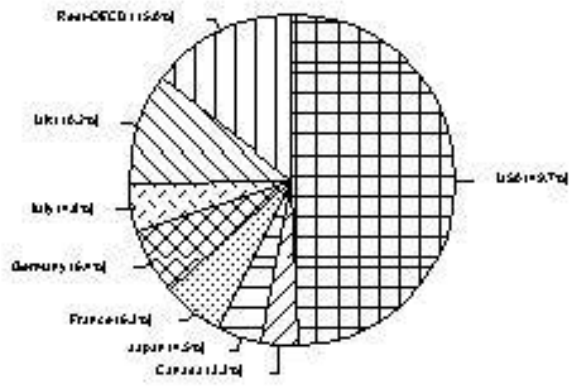

1955

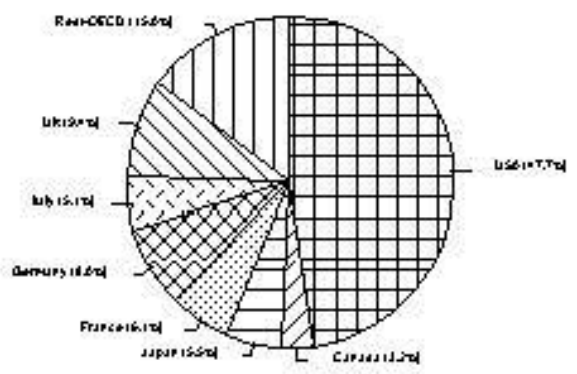




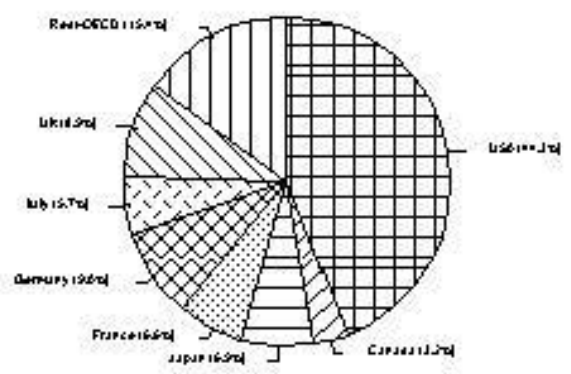

1965

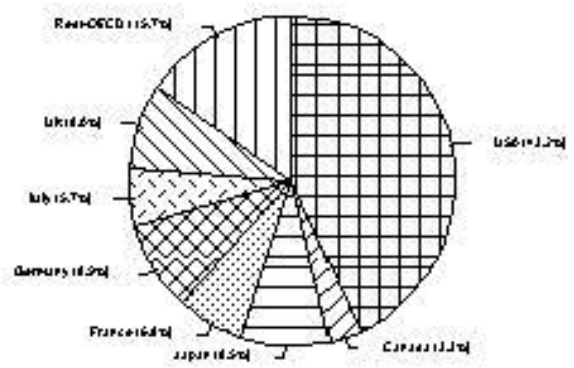




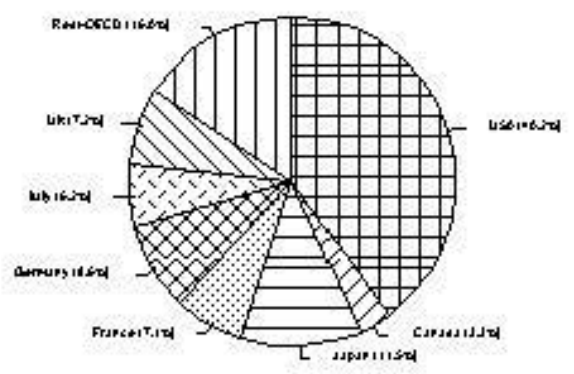

1975

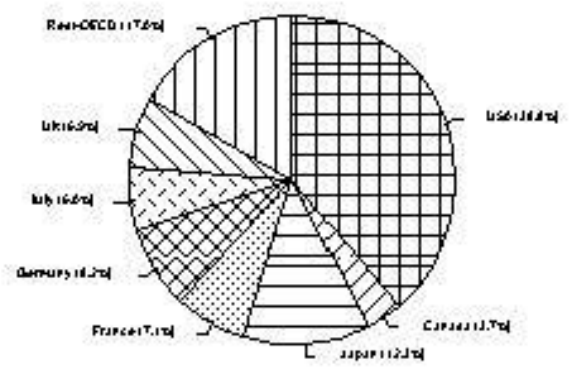




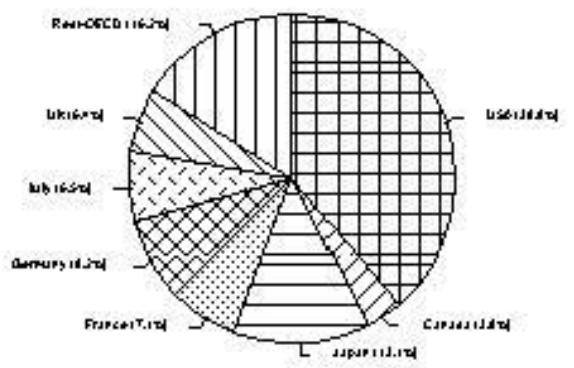

1985

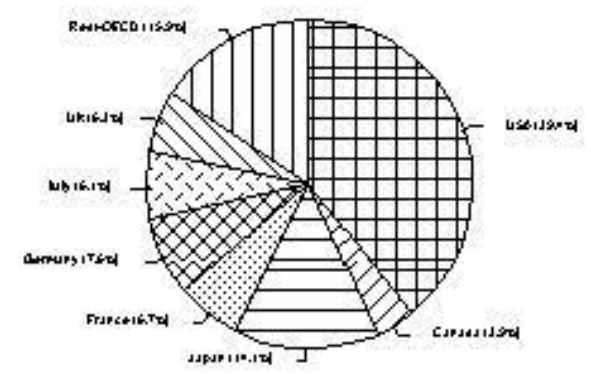

1990

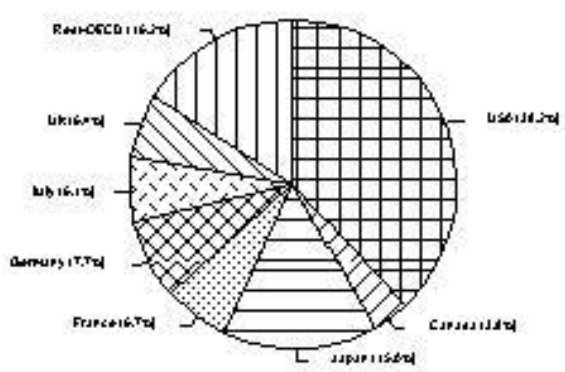

[Page is

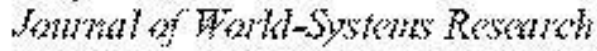

\section{Endinotes}


1. We would like to thank the National Bureau of Economic Research, which provides the scientific community with the public good of the Penn World Tables via the Internet. Our thanks go also to Matthias Kenter, Institut der deutschen Wirtschaft, Cologne, for helpful hints concerning the data. For their various constructive comments we are indebted to Margaret Levi, Matthias Mohr and Fritz W. Scharpf.

2. It is much disputed whether stabilized exchange rates are to be considered a public good or public bad. We are not concerned with this question, but in general we agree with the economic mainstream that fixed exchange rates are a public bad while stable and stabilized exchange rates are a public good.

3. Confusingly, economists define this role as leadership, while international relations scholars distinguish between a single leader, called hegemon, and a group of leaders. These differences are mainly ignored in economic theory. However, as we show later, the analytical separation of hegemons and leaders does make sense. Therefore, we rigidly differentiate between a single leader, referred to as a hegemon, and multiple joint leaders.

4. For the suggestion that there is a continuum between pure public and pure private goods rather than a dichotomy, see Bruce Russett (1987: 225).

5. We will discuss and amend this assumption in sections 5 and 7.

6. We have experimented with logistic functions of arbitrary complexity for the transaction costs, which do not change the nature of the results.

7. We acknowledge the critique of John Ruggie (1982) and David Lake (1984) that relative size can explain only the necessary, but not the sufficient, conditions for the emergence of a liberal international economy. We nevertheless think it makes sense to provide international relations scholars with the analytical tools to analyze the politicaleconomic consequences of size within the game -theoretic approach to international politics.

8. The Penn World Tables, also known as the Summers-Heston Tables, display a set of national accounts economic time-series covering a large number of countries. It is an attempt to get closer to a system of real national accounts, and its unique feature is that it allows for international, not just intertemporal, comparisons (Summers/ Heston 1991).

9. It is debatable whether the EC (or an equivalent thereof) had the strategic capability of acting as an actor in the 1950s and early 1960s. An interesting discussion of whether corporate actors, coalitions, collective actors, and aggregate actors can be treated as unitary players applicable for game-theoretic analysis is provided by Scharpf (1991). It might be argued that the EC until the early 1960 s was an aggregate actor without strategic capability and thus only capable of choosing the strategy of following, which provides further support for the early $[\mathrm{H}, \mathrm{F}, \mathrm{F}]$ equilibrium. However, the early EC consisted of certain dominant subactors such as Germany, France, and the UK, which either alone or through some mechanism of tacit self-coordination could engage in 
strategic action. This justifies considering the $\mathrm{EC}$ as an actor in its own right as early as the $1950 \mathrm{~s}$.

10. See also James Morrow (1994a) for an integration of coercive and benevolent leadership. Note that our model differs from Morrow's model, even though we agree that leaders need not be superior. We assume that they must have a minimum size, which is determined by the cost of the public good. Therefore, actors can be leaders in one issue area while they fail to lead in another.

11. For a more general discussion of whether actors have the incentives to punish deviators to ensure cooperation or rule compliance, see Boyd and Richerson (1985, 1992).

[Page 87]

Journal of World-Systems Research

\section{$\underline{\text { References }}$}

Alt, James E./Randell L. Calvert/Brian D. Humes, 1988: Reputation and Hegemonic Stability: A Game-Theoretic Analysis. In: American Political Science Review 82, $445-$ 466.

Aron, Raymond, 1962: Peace and War: A Theory of International Relations. Garden City: Doubleday.

Axelrod, Robert, 1984: The Evolution of Cooperation. New York: Basic Books.

Brams, Stephen J., 1975: Game Theory and Politics. New York: Macmillan.

Boyd, Robert/Peter J. Richerson, 1985: Culture and the Evolutionary Process. Chicago: University of Chicago Press.

Boyd, Robert/Peter J. Richerson, 1992: Punishment Allows the Evolution of Cooperation (or Anything Else) in Sizable Groups. In: Ethology and Sociobiology 13, 171-195.

Carr, Edward H., 1946: The Twenty Years' Crisis. London: St. Martin's Press.

Colomer, J.M., 1995: Leadership Games in Collective Action. In: Rationality and Society $7,225-246$.

Conybeare, John A.C., 1984: Public Goods, Prisoners' Dilemmas and the International Political Economy. In: International Studies Quarterly 28, 5-22. 
Frey, Bruno, 1984: The Public Choice View of International Political Economy. In: International Organization 38, 199-223.

[Page 88]

Journal of World-Systems Research

Funabashi, Yoichi, 1988: Managing the Dollar: From the Plaza to the Louvre. Washington: Institute for International Economics.

Gilpin, Robert, 1987: The Political Economy of International Relations. Princeton: Princeton University Press.

Grieco, Joseph M., 1990: Cooperation among Nations. Ithaca: Cornell University Press.

Gowa, Joanne, 1989: Rational Hegemons, Excludable Goods, and Small Groups. In:

World Politics 41, 307-324.

Hardin, Russell, 1982: Collective Action. Baltimore: Johns Hopkins University Press.

Kennedy, Paul, 1987: The Rise and Decline of Great Powers: Economic Change and Military Conflict from 1500-2000. New York: Random House.

Keohane, Robert O., 1980: The Theory of Hegemonic Stability and Changes in International Economic Regimes, 1967-1977. In: Ole Holsti et al. (eds.), Change in the International System. Boulder, CO: Westview Press, 131-162.

Keohane, Robert O., 1984: After Hegemony: Cooperation and Discord in the World Political Economy. Princeton: Princeton University Press.

Keohane, Robert O./Joseph Nye, 1977: Power and Interdependence. Boston: Little, Brown.

Kindleberger, Charles P., 1973: The World in Depression, 1929-39. Berkeley: University of California Press.

[Page 89]

Journal of World-Systems Research

Kindleberger, Charles P., 1976: Systems of International Economic Organization. In: David P. Calleo (ed.), Money and the Coming World Order. New York: New York University Press, 15-39. 
Kindleberger, Charles P., 1981: Dominance and Leadership in the International Economy: Exploitation, Public Goods, and Free-Rides. In: International Studies Quarterly 25, 242-254.

Kindleberger, Charles P., 1986: International Public Goods without International Government. In: American Economic Review 76, 1-13.

Krasner, Stephen D., 1976: State Power and the Structure of International Trade. In: World Politics 28, 317-345.

Lake, David A., 1984: Beneath the Commerce of Nations: A Theory of International Economic Structures. In: International Studies Quarterly 28, 143-170.

Lake, David A., 1993: Leadership, Hegemony, and the International Economy: Naked Emperor or Tattered Monarch with Potential. In: International Studies Quarterly 37, 459489.

Martin, Lisa L., 1993: The Rational State Choice of Multilateralism. In: John Gerard Ruggie (ed.), Multilateralism Matters. The Theory and Praxis of an Institutional Form. New York: Columbia University Press, 91-121.

McKeown, Timothy J., 1983: Hegemonic Stability Theory and 19th Century Tariff Levels in Europe. In: International Organization 37, 73-91.

Milner, Helen, 1992: International Theories of Cooperation among Nations: Strengths and Weaknesses. In: World Politics 44, 466-496.

[Page 90]

Journal of World-Systems Research

Morgenthau, Hans J., 1948/1973: Politics among Nations. New York: Knopf.

Morrow, James D., 1994a: Modeling the Forms of International Cooperation:

Distribution versus Information. In: International Organization 48, 387-423.

Morrow, James D., 1994b: Game Theory for for Political Scientists. Princeton: Princeton University Press.

Olson, Mancur, 1965/1971: The Logic of Collective Action: Public Goods and the Theory of Groups. Cambridge, MA: Harvard University Press.

Olson, Mancur/Richard Zeckhauser, 1966: An Economic Theory of Alliances. In: Review of Economics and Statistics 48, 266-279. 
Oye, Kenneth A., 1985: Explaining Cooperation under Anarchy: Strategies and Institutions. In: World Politics 38, 1-24.

Ruggie, John G., 1982: International Regimes, Transactions, and Change: Embedded Liberalism in the Postwar Economic Order. In: International Organization 36, 379-415.

Russett, Bruce, 1987: The Mysterious Case of Vanishing Hegemony: Or, Is Mark Twain Really Dead? In: International Organization 39, 207-231.

Scharpf, Fritz W., 1991: Games Real Actors Could Play: The Challenge of Complexity. In: Journal of Theoretical

[Page 91]

Journal of World-Systems Research

Politics 3, 277-304.

Scharpf, Fritz W./Matthias Mohr, 1994: Efficient Self-Coordination in Policy Networks: A Simulation Study. MPIFG Discussion Paper 94/1. Köln: Max-Planck-Institut für Gesellschaftsforschung.

Schelling, Thomas C., 1960: Strategy of Conflict. Cambridge, MA: Harvard University Press.

Snidal, Duncan, 1985a: The Limits of Hegemonic Stability Theory. In: International Organization 39, 579-603.

Snidal, Duncan, 1985b: The Game Theory of International Politics. In: World Politics 38 , 25-57.

Stein, Arthur A., 1984: The Hegemon's Dilemma: Great Britain, the United States, and the International Economic Order. In: International Organization 38, 355-386.

Strange, Susan, 1987: The Persistent Myth of Lost Hegemony. In: International Organization 41, 551-574.

Summers, Robert/Alan Heston, 1991: The Penn World Table (Mark 5): An Expanded Set of International Comparisons, 1950-1988. In: Quarterly. Journal of Economics 106, 327 368 .

Taylor, Michael, 1976: Anarchy and Cooperation. London: Wiley.

Thurow, Lester, 1992: Head to Head: The Coming Economic Battle among Japan, Europe, and America, London: Nicholas Brealy. 
Tsebelis, George, 1990: Nested Games: Rational Choice in Comparative Politics. Berkeley: University of California Press.

[Page 92]

Journal of World-Systems Research

Wallerstein, Immanuel, 1980: The Modern World-System II: Mercantilism and the Consolidation of the European World-Economy, 1600-1750. New York: Academic Press.

Waltz, Kenneth N., 1979: Theory of International Politics. New York: McGraw-Hill.

Yarbrough, Beth V./ Robert M. Yarbrough, 1992: Cooperation and Governance in International Trade: The Strategic Organizational Approach. Princeton: Princeton University Press.

[Page 93$]$

Journal of World-Systems Research 